\title{
Biomechanical and biochemical effects recorded in the tree root zone - soil memory, historical contingency and soil evolution under trees
}

\author{
Lukasz Pawlik (D) Pavel Šamonil
}

Received: 17 September 2017 / Accepted: 1 March 2018 / Published online: 15 March 2018

(C) The Author(s) 2018

\begin{abstract}
Background and aims The changing soils is a neverending process moderated by numerous biotic and abiotic factors. Among these factors, trees may play a critical role in forested landscapes by having a large imprint on soil texture and chemical properties. During their evolution, soils can follow convergent or divergent development pathways, leading to a decrease or an
\end{abstract}

Highlights

1) The architecture of tree root systems controls soil physical and chemical properties.

2) The predominating pedogenetic process significantly modifies the effect of trees on soil.

3) Trees are a factor in polygenesis in Haplic Cambisols at the pedon scale.

4) Trees intensify podzolization and increase pedomorphic complexity in Albic Podzols.

5) Under trees in Entic Podzols, Ah and B horizon thicknesses increased, and soil chemistry changed.

Responsible Editor: Alexia Stokes.

Ł. Pawlik

Department of Climatology, University of Silesia in Katowice, ul. Będzińska 60, 41-200 Sosnowiec, Poland

\section{Ł. Pawlik $(\bowtie)$}

Institute of Geography, Pedagogical University of Cracow, ul. Podchorążych 2, 30-084 Kraków, Poland

e-mail: lukasz.pawlik@us.edu.pl

P. Šamonil

Department of Forest Ecology, The Silva Tarouca Reseach Institute for Landscape and Ornamental Gardening, Lidická 25/27, 65720 Brno, Czech Republic increase in soil spatial complexity. We hypothesized that trees can be a strong local factor intensifying, blocking or modifying pedogenetic processes, leading to local changes in soil complexity (convergence, divergence, or polygenesis). These changes are hypothetically controlled by regionally predominating soil formation processes.

Methods To test the main hypothesis, we described the pedomorphological features of soils under tree stumps of fir, beech and hemlock in three soil regions: Haplic Cambisols (Turbacz Reserve, Poland), Entic Podzols (Žofínský Prales Reserve, Czech Republic) and Albic Podzols (Upper Peninsula, Michigan, USA). Soil profiles under the stumps, as well as control profiles on sites currently not occupied by trees, were analyzed in the laboratory for 20 physical and chemical properties. In total, we analyzed 116 soil samples. The age of trees and time of tree death were determined using the radiometry $\left({ }^{14} \mathrm{C}\right)$, dendrochronology and repeated tree censuses. To process the data, we used multivariate statistics, namely, redundancy analyses (RDAs) and principal component analyses (PCAs). The statistical significance of variables was tested using Kruskal-Wallis, Dunn, and permutation tests. To reach the main aims of the present study, we examined the dataset at three levels of data complexity: 1) soil regions, 2) microsite (i.e., tree stump versus control site), and 3) soil horizon.

Results Living tree roots and empty or infilled root channels were the most important pedogenic factors that affected the dimensions of soil horizons and the moisture in the root zone under tree stumps. Microsites explained almost $6 \%$ of the soil variability $(p<0.001$, 
$\mathrm{F}=13.99$ ), demonstrating that trees significantly impacted soil chemical properties in the root zone in all regions. In the Albic Podzols soil region, we found evidence of "basket" podzolization. Our results suggest the rapid eluviation of organic matter-sesquioxide complexes under the stump, probably leading to local soil divergence in Albic Podzols. However, soil analyses under the stumps in the Haplic Cambisols soil region suggested local polygenetic changes in soils (e.g., hydromorphic processes). The thickness of the A and B horizons increased, and soil chemistry changed under trees in the Entic Podzol soil region compared to the control profiles.

Conclusions In addition to regional environmental factors that manifest themselves in regional pedogenesis and that have a key role in modifying the influence of trees on the soil, the tree species can specifically modify pedogenic processes under standing trees. Trees may influence rate of pedogenesis (hemlock in Albic Podzol region) or even soil evolutionary pathways (beech in Haplic Cambisol region).

Keywords Forest soil · Tree-soil interactions · Nonlinear pedogenesis - Deterministic chaos · Podzols . Cambisols $\cdot$ Beech $\cdot$ Fir $\cdot$ Hemlock

\section{Introduction}

Forest soils are constantly directly and indirectly influenced by trees through biomechanical and biochemical effects of their root systems, trunks and leaves decay etc. (Binkley and Giardina 1998; Phillips and Marion 2004, 2006; Pawlik et al. 2016). Additionally, soil microbes and mycorrhizas form several complex symbioses with tree roots and together act as a powerful "weathering engine" (Uroz et al. 2009; Hasenmueller et al. 2017). Geomorphology, soil science, and forest ecology have already recognized several processes that impact weathering intensity, forest dynamics and soil evolution. Among these processes, tree uprooting and root growth and decay seem to be the most effective processes in temperate forests (Gabet et al. 2003; Gabet and Mudd 2010; Pawlik 2013; Pawlik et al. 2013, 2016, 2017; Phillips 2008; Phillips et al. 2015, 2017; Šamonil et al. 2017, 2018b).

The biochemical impact of trees in terms of space, soil material and processes operating under trees and tree stumps has not been adequately studied (Binkley and Giardina 1998; Riebe et al. 2017; Brantley et al. 2011,
2017). Such interdisciplinary studies were seriously limited in the past mainly due to an insufficient understanding of crucial pedogenetic processes and limited capabilities of laboratory techniques. In addition, a priori assumptions stated that the effects of individual trees were not significant, and if there were any changes in soils, their effects were mutually reset at the stand and landscape scales. However, many studies revealed spatially non-random and long-term effects of individual trees in some soils (e.g., Mossa and Schumacher 1993, Phillips 2001, Phillips and Marion 2004; Šamonil et al. 2014) and pedochemical changes in soils under trees. For instance, in the Great Lakes region, Bloomfield (1953) and Schaetzl (1990) described significantly developed so-called "basket" or "egg cup" Albic Podzols under trees. Unfortunately, these pedochemical studies are rare and have been exclusively conducted in a region of Albic Podzols. There is minimal understanding of these pedogenetic processes in other regions. Šamonil et al. (2018a) revealed even inverse impact of individual trees in pedogenesis in dependence on regionally predominating soil formation process.

Soils may exhibit traditional, stable, or non-chaotic modes of formation, but they also may become unstable, chaotic and self-organizing (Huggett 1998; Phillips 2006; Walker et al. 2010). Dynamic instability and deterministic chaos are characterized by sensitivity to minor variations in initial conditions and to small local disturbances (Phillips et al. 1996; Phillips 1999, 2013; FavisMortlock 2013). In forested landscapes, disturbances are frequently associated with the effects of individual trees (Phillips and Marion 2004). Both modes - chaotic and non-chaotic - participate in forming the complexity of the soil landscape (Phillips 1999, 2017). However, such complexity as a result of chaos does not mean disorder because "order is an emergent property of the unstable, chaotic system" (Phillips 1999; p. 71). For example, pedoturbations may lead to the development of stone layers (Johnson and Watson-Stegner 1987). Trees can be a factor leading to the development of texture contrast soils (Phillips 2007). Furthermore, powerful feedbacks between biota and soils cause a mutual dependence in both systems (Corenblit et al. 2011; Verboom and Pate 2013; Schaetzl and Thompson 2015).

Our research questions in the context of this study are as follows:

1) Do trees influence soil chemical properties and horizonation through stem flow and root systems impact? 
2) Do root systems impact biochemical and biomechanical weathering in soils and regolith?

3) What kind of long-term effects detected in soils can be attributed to tree roots?

4) What is the effect of soil region and tree species on below-stump pedogenesis?

5) Are trees a factor in divergent soil evolution and, as a result, a factor in soil complexity?

\section{Materials and methods}

Study sites

Because of our attempt to test general rules of soil development under trees, we chose tree individuals in three different soil regions: Haplic Cambisols (Turbacz Reserve in Gorce Mts. National Park, Poland), Entic Podzols (Zofin Reserve in Novohradske Mountains in the Czech Republic), and Albic Podzols (Upper Peninsula, Michigan, USA). Although these soils cannot easily be considered developmental steps of one trajectory of pedogenesis, these three soil regions are dominated by weathering and leaching processes of varying severities (Fig. 1, Table 1).

\section{Turbacz on Haplic Cambisols (flysch)}

Turbacz Forest Reserve (hereafter Turbacz) is 319 ha in size and was re-established in 1964. Today, it belongs to Gorce Mts. National Park, which was established in 1981. It is situated in the Outer Western Carpathians region. From a geological viewpoint, Gorce Mts. belongs to the Magura Nappe and Turbacz area and is predominantly built of sandstones and shales. The entire region of Gorce Mts. has been affected in the past by landslide events. However, our study site does not bear any visible traces of landslides (relict or contemporaneous). The dominant tree species are fir (Abies alba Mill.) and European beech (Fagus sylvatica L.). The soils are predominantly Cambisols. The climate of Gorce Mts. is harsh, with a mean annual temperature $3-6{ }^{\circ} \mathrm{C}$ and a mean annual precipitation from 800 to $1200 \mathrm{~mm}$ (Miczyński 2015).

\section{Zofin on Entic Podzols (granite)}

Žofínský prales National Nature Reserve (hereafter Zofin) represents the fourth oldest forest reserve in
Europe and the first FirestGeo research plot in continental Europe (www.forestgeo.si.edu). The core zone has never been cut. The bedrock is almost homogeneous and consists of medium-grained porphyritic and biotite granite (www.geology.cz). The average annual rainfall is 866 $\mathrm{mm}$, and the mean annual temperature is $6.2{ }^{\circ} \mathrm{C}$ (www. chmi.cz). Fagus sylvatica currently dominates in the forest (62\% of volume of living trees), followed by Picea abies (34\%). Abies alba and other tree species (Acer pseudoplatanus, A. platanoides, Sorbus aucuparia, Ulmus glabra) represent $3 \%$ and $1 \%$ of the living tree volume, respectively (e.g. Šamonil et al. 2014).

Upper Peninsula on Albic Podzols (outwash)

The Munising site is dominated by northern hardwoods selectively cut no later than 40 years ago. The bedrock is built of sandy glacial outwash on which Albic Podzols developed as a dominant soil unit. The forest cover is mixed, with maple (Acer saccharum Marsh., A. rubrum L., A. saccharinum L.), cherry (Prunus serotina Ehrh.), red oak and eastern hemlock (Quercus rubra L. and Tsuga Canadensis (L.) Carr.). The study site is at an altitudinal range of $215-270 \mathrm{~m}$. The mean average temperature is $5.1^{\circ} \mathrm{C}$, and the mean annual precipitation is approximately $800 \mathrm{~mm}$.

Soil sampling strategy

We sampled soil profiles under decayed tree stumps at three study sites (see above). We subjectively selected one large fir stump and one beech stump in the Haplic Cambisol and Entic Podzol regions. In the third region, occupied by a different composition of woody species, we selected one old hemlock stump. Tsuga canadensis is generally considered to be the most soil acidifying woody species of northern hardwoods because of high amount of aggressive organic acids released during the metabolism and leafs and roots decay. We selected this tree species because we expected it to have the most significant effects on soils. First develop some large lateral roots and one large taproot that can penetrate a soil profile to the significant depth (up to $2 \mathrm{~m}$ ). Beech root system can be well developed in a horizontal and vertical direction with a complex architecture of wooden and non-wooden roots and usually miss the taproot.

A soil trench was made through the entire trunk base and root system perpendicular to the slope inclination and at a depth of about $100 \mathrm{~cm}$. In all three soil regions, 

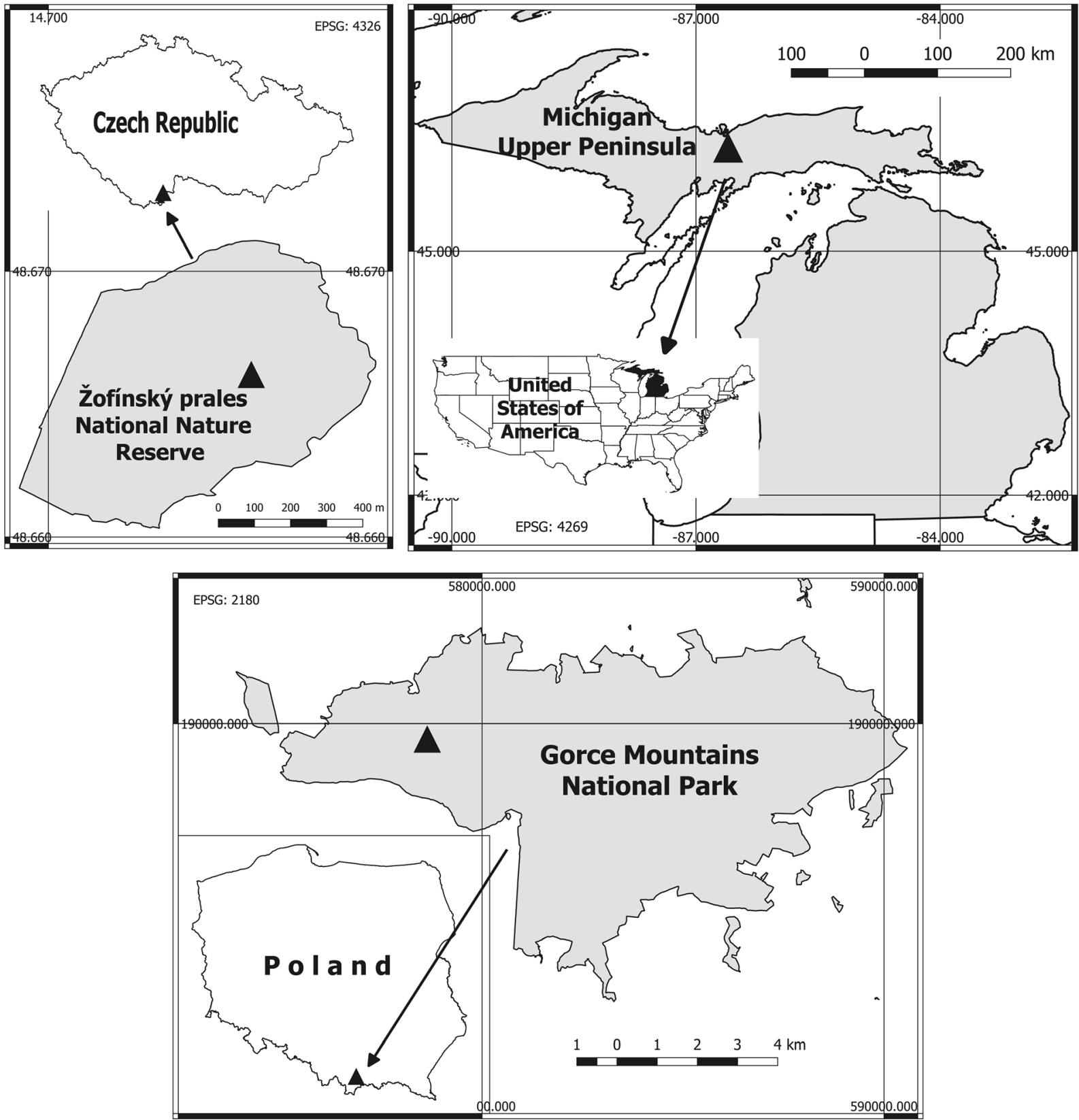

Fig. 1 Maps of the study sites

we first sampled soil profiles directly under the center of tree stumps, through the root zones and to the substratum soil horizon. Additional soil profiles were sampled at the edges of the fir and beech stumps in Turbacz and Zofin, where we assumed potential changes in soil evolutionary pathways due to stem flow. Configuration of profiles was largely dependent on root system architecture and regolith properties (e.g., large blocks of bedrock that limited the soil profile depth). Then, the control soil profile was dug and sampled in an adjacent site that was not directly affected by living or dead trees. Each soil profile was sampled in a systematic way every $5-10 \mathrm{~cm}$ up to $50 \mathrm{~cm}$ depth and every $20 \mathrm{~cm}$ up to $100-110 \mathrm{~cm}$ depth. The remnants of decayed tree stumps and the upper organic horizons (in the case of the control profiles) were taken for laboratory analysis. In total, 10 samples were taken in Munising, 44 in Zofin and 69 in Turbacz. 
Table 1 Main features of the study sites

\begin{tabular}{llll}
\hline Feature/locality & Turbacz & Zofin & Munising \\
\hline Parent material & flysch & granite & glacial outwash \\
Soils & Haplic Cambisols (HC) & Entic Podzols (EP) & Albic Podzols (AP) \\
Forest & fir-beech forest & (spruce)-fir-beech forest & northern-hardwood \\
Dominant tree species & Fagus sylvatica, Abies alba & Fagus sylvatica, Abies alba, & Acer saccharum, A. rubrum, \\
& & Picea abies & Quercus rubra, Tsuga canadensis \\
Altitude of study site $(\mathrm{m}$ a.s.l.) & 950 & $730-837$ & $215-270$ \\
Mean slope inclination $\left({ }^{\circ}\right)$ & 15 & 9 & 7 \\
Mean annual precipitation $(\mathrm{mm})$ & 1000 & 866 & 800 \\
Mean annual temperature $\left({ }^{\circ} \mathrm{C}\right)$ & $3.0-6.0$ & 6.2 & 5.1 \\
\hline
\end{tabular}

\section{Data analyses}

Dating of trees and their disturbances

We studied the (i) age of excavated trees and (ii) time of tree death separately.

i. For coarse tree age evaluation, we collected wood samples from remnants of stumps for AMS ${ }^{14} \mathrm{C}$ dating (Acceleration Mass Spectrometry). From the face of the trench, we sampled the oldest parts of the trunk or roots by hand or with a dendrochronological corer (in case of younger stumps). We took at least one sample per stump. All samples were dated in the Poznan Radiocarbon Laboratory (Poz; www.radiocarbon.pl). The minimal age of relatively fresh stumps was evaluated using dendrochronological analysis of main roots. The median $14 \mathrm{C}$ age was calculated using OxCal software (https://c14.arch.ox.ac. uk/oxcal.html).

ii. Time of tree death was studied with several techniques. In Zofin and Michigan, we used a dendrochronological dating technique established by Šamonil et al. (2013). We cored trees surrounding the dead tree stump, and we looked for their radial growth response to disturbance. Unfortunately, this technique was prohibited in Turbacz Reserve. Instead, we counted the number of incremental rings of tinder fungus (Fomes fomentarius L. Fr.) growing on a lying fir trunk. Fomes fomentarius is characterized by geotropically growth and therefore its horizontal growth on lying tree trunk represents minimal age of disturbance.
In Zofin, we also used a unique data set of repeated tree censuses (e.g. Šamonil et al. 2013) for dating tree deaths. For this measurement, we evaluated the dimensions and health status of all living and dead trees of $\mathrm{DBH} \geq 10 \mathrm{~cm}$ in 1975,1997 , and 2008 in the locality. The trees recorded in 1975 were repeatedly identified in 1997 and then in 2008 with using exact map of trees and their current characteristics were assessed. By comparison of tree censuses we roughly uncovered time of tree death.

\section{Laboratory analyses of soils}

We conducted numerous chemical analyses that allowed us to evaluate the main soil-forming processes in soils affected and unaffected by trees. We focused on soil weathering and leaching processes, the formation of secondary minerals, clay translocation, podzolization, melanization, and hydromorphic processes.

Samples from Zofin and Munising were analyzed according to Zbíral $(2002,2003)$ and Zbíral et al. (2004). These soil samples were subject to the following laboratory procedures: oxidizable $\mathrm{C}$ (Cox), determined spectrophotometrically after oxidation by $\mathrm{H}_{2} \mathrm{SO}_{4}+$ $\mathrm{K}_{2} \mathrm{Cr}_{2} \mathrm{O}_{7}$ (Anonymous 1995); $\mathrm{C}$ content in total humic substances (C-THS) and $\mathrm{C}$ content in humic acids (C$\mathrm{HA}$ ) and fulvic acids (C-FA), determined in $\mathrm{Na}_{4} \mathrm{P}_{2} \mathrm{O}_{7}$ (Jandák 1989; method modified according to Kononova and Bel'chikova 1961); color quotient (Q4/6, $\mathrm{Na}_{4} \mathrm{P}_{2} \mathrm{O}_{7}$ extract; Chen et al. 1977); total $\mathrm{N}$ content (Kjeldahl method; Bremner 1996); exchange soil reaction (pH$\mathrm{KCl}$ ) in $0.2 \mathrm{M} \mathrm{KCl}$; and active soil reaction in water $\left(\mathrm{pH}-\mathrm{H}_{2} \mathrm{O}\right)$. The contents of $\mathrm{Fe}, \mathrm{Al}, \mathrm{Mn}$ and $\mathrm{Si}$ were determined by different extraction methods: 
1. For crystalline forms $\left(\mathrm{Al}_{\mathrm{d}}, \mathrm{Fe}_{\mathrm{d}}, \mathrm{Mn}_{\mathrm{d}}, \mathrm{Si}_{\mathrm{d}}\right)$, an extraction with a dithionite-citrate solution was used (McKeague and Day 1966; McKeague et al. 1971) at a ratio of 0.5:25 $(w / v)$ according to Courchesne and Turmel (2008).

2. For amorphous forms and organic complexes $\left(\mathrm{Al}_{\mathrm{ox}}\right.$, $\left.\mathrm{Fe}_{\mathrm{ox}}, \mathrm{Mn}_{\mathrm{ox}}, \mathrm{Si}_{\mathrm{ox}}\right)$, an extraction with ammonium oxalate was conducted in the dark (McKeague and Day 1966; Courchesne and Turmel 2008) with $0.2 \mathrm{M}$ of ammonium oxalate at $\mathrm{pH} 3$ (at a ratio of $0.25: 10, \mathrm{w} / \mathrm{v})$.

3. For labile forms $\left(\mathrm{Al}_{\mathrm{k}}, \mathrm{Fe}_{\mathrm{k}}, \mathrm{Mn}_{\mathrm{k}}, \mathrm{Si}_{\mathrm{k}}\right)$, contents were determined in $0.5 \mathrm{M} \mathrm{KCl}\left(37.27 \mathrm{~g}^{-1}\right)(1: 10, v / w)$ (Drábek et al. 2003, 2005).

The final concentrations of $\mathrm{Fe}, \mathrm{Al}, \mathrm{Mn}$ and $\mathrm{Si}$ were measured with ICP-OES (with an iCAP 6500 Radial ICP Emission spectrometer; Thermo Scientific, UK).

Samples from Turbacz were subject to standard procedures described in Buurman et al. (1996) and the Polish norms for soil and water analysis (PN-EN ISO 18134-1, PN-EN ISO 16948, PN-EN 15933). Oxidizable carbon (Cox) and total nitrogen $(\mathrm{N})$ were determined according to PN-EN ISO 16948. Forms of Fe, Al, Mn and Si were extracted after dissolution with dithionite in a buffer of citrate and dithionite (Buurman et al. 1996). The extracted elements were then detected with ICP-OES (Inductively Coupled Plasma Optical Emission Spectroscopy) using an iCAP 6000 series.

Because our soil samples were analyzed in two laboratories, the methodological approaches were slightly different, but this did not affect the assumed level of comparability of data from Turbacz, Zofin and Munising.

\section{Data processing}

All data were subject to standard statistical analyses. Apart from basal descriptive statistics, we used a Kruskal-Wallis rank sum test to determine whether the mean ranks were the same in all the groups defined by the main soil regions (nominal variable). We used this test because some of the data deviated from normality (as determined by the Shapiro-Wilk normality test). The results of the Kruskal-Wallis test were confirmed with a two-sided Dunn test for multiple comparisons (Dunn 1964), which is appropriate for groups with unequal numbers of observations (Zar 2010). The $p$-values from the Dunn test were adjusted with the Bonferroni method
(Dinno 2016; Ogle 2017). We looked for differences between soil groups by taking into consideration the soil profiles under the tree stumps and in our control sites. For each study area, we also calculated correlation coefficients between variables using Spearman's rank method with Holm (1979) adjustment for multiple comparisons (Revelle 2017). For all analyses, we assumed the significance level to be $\alpha=0.05$. All analyses were conducted in the R software environment for statistical computing and graphics (R Core Team 2016). We used the following libraries: stats, aqp (Beaudette et al. 2013), FSA (Ogle 2017), psych (Revelle 2017), vegan and ggvegan (Oksanen et al. 2017), ggplot2 (Wickham and Chang 2016) and ggbiplot (Vincent 2011).

We further used two ordination techniques: principal component analyses (PCA) and redundancy analysis (RDA). RDA is based on Euclidean distances and performs linear mapping (Ramette 2007). The results of the RDA were checked for significance by means of an ANOVA and a Monte Carlo permutation test with 4999 permutations. We checked the significance of the explained variation against the null hypothesis that the variability occurs only by a chance. Prior to analysis, the response variables were log-transformed (with the natural logarithm) and standardized because of deviations from the normal distribution and the dimensional homogeneity (different units of measurements) of the data (Ramette 2007; Buttigieg and Ramette 2014). To reach the main aims of the present study, we examined the data set at three levels of data complexity: 1) soil regions, 2) microsites, and 3) soil horizons.

\section{Results}

Timeframe using the tree census and radiocarbon and dendrochronological dating

In total, we found 111, 115 and 135 tree rings in three main roots of Tsuga canadensis, which means that this tree has to be at least 135 years old (Table 2). We also counted 262 and 263 tree rings in two main roots of Fagus sylvatica on Entic Podzols, which means this tree has to be at least 263 years old. Because of the advanced wood decay, dendrochronological analysis could not be used in other cases.

We conclude that the time since death is no longer than 8 years in the case of the beech stumps and between 19 and 41 years in the case of fir stump in the EP soil 
Table 2 Results of radiocarbon dating $\left({ }^{14} \mathrm{C}\right.$, AMS) and dendrochronological analyses of wood samples and roots

\begin{tabular}{|c|c|c|c|c|c|c|}
\hline \multirow{2}{*}{$\begin{array}{l}\text { Laboratory } \\
\text { No } \\
\text { Turbacz - HC }\end{array}$} & \multirow{2}{*}{$\begin{array}{l}\text { Radiocarbon } \\
\text { age (years, BP) }\end{array}$} & \multirow{2}{*}{$\begin{array}{l}\text { Calibrated age ( } 95.4 \% \\
\text { probability, years, AD) }\end{array}$} & \multirow{2}{*}{$\begin{array}{l}\text { Median cal. 14C } \\
\text { age (years, AD) }\end{array}$} & \multirow[t]{2}{*}{ Notes } & \multicolumn{2}{|c|}{ Dendrochronology } \\
\hline & & & & & & \\
\hline \multicolumn{7}{|l|}{$\begin{array}{l}\text { Po- } \\
\mathrm{Z}^{*}-85090\end{array}$} \\
\hline Poz-85091 & $95 \pm 30$ & $1682-1931$ & 1841 & wood from taproot of fir & & \\
\hline Poz- 85092 & $80 \pm 30$ & $1690-1926$ & 1846 & wood from tree stump & - & - \\
\hline Poz- 85093 & $\begin{array}{l}100.44 \pm 0.31 \\
\mathrm{pMC}\end{array}$ & - & - & modern (wood from tree stump) & & \\
\hline Poz-85095 & $120 \pm 30$ & $1679-1940$ & 1832 & remnants of tree trunk building a stump & & \\
\hline \multicolumn{7}{|l|}{ Zofin - EP } \\
\hline Poz- 88070 & $130 \pm 30$ & $1675-1942$ & 1822 & $\begin{array}{l}\text { The deepest part of tree ring from the } \\
\text { stump - edge of inner rotten wood }\end{array}$ & $\begin{array}{c}262,263 \\
\text { rings }\end{array}$ & $\begin{array}{l}\text { Main roots of } \\
\text { F. sylvatica }\end{array}$ \\
\hline Poz-88071 & $220 \pm 40$ & $1524-1917$ & 1760 & $\begin{array}{l}\text { Wood sample from the stump - area clos- } \\
\text { est to the pith, } 0.2 \mathrm{~m} \text { above surface }\end{array}$ & - & - \\
\hline \multicolumn{7}{|c|}{ Munising/Michigan - AP } \\
\hline Poz- 88072 & $135 \pm 30$ & $1671-1943$ & 1815 & $\begin{array}{l}\text { Wood sample from the stump - area clos- } \\
\text { est to the pith, } 0.5 \mathrm{~m} \text { above surface }\end{array}$ & $\begin{array}{l}111,115 \\
135 \\
\text { rings }\end{array}$ & $\begin{array}{l}\text { Main roots of } \\
\text { T. canaden- } \\
\text { sis }\end{array}$ \\
\hline
\end{tabular}

*Poznań Radiocarbon Laboratory (www.radiocarbon.pl)

region. Five of the six cored trees surrounding hemlock stumps in Michigan were released in their radial growth after 1978. Positive percent-growth changes reached $30-361 \%$ of the primary growth since 1979 . This result suggests that the Tsuga canadensis was disturbed and died probably 35 years ago. The incremental rings of tinder fungus (Fomes fomentarius L. Fr.) growing on a lying fir trunk in the $\mathrm{HC}$ region (Turbacz) showed that the tree broke at least 10 years before sampling in 2016.

The results of radiocarbon dating and dendrochronology show that the investigated trees could have impacted soil within the microsites for approximately 100-300 years (median radiocarbon age was between $1760 \mathrm{AD}$ and 1846 AD, Table 2). We did not find lenses of relict root channels or buried organic horizons, or hydromorphic changes associated with entirely decomposed tree roots. Tree individuals probably did not occupied the same site as the previous, already decayed tree.

Soil regions - predominant impact of the type of bedrock

The crucial gradient of the whole dataset (1st noncanonical axis) explained $37.8 \%$ of the variation in the data (Principal Component Analysis, PCA, Fig. 2). The differences in soil chemical properties between Haplic Cambisols (HC), Entic Podzols (EP) and Albic Podzols (AP) were clearly visible in the raw data (Appendix 1),

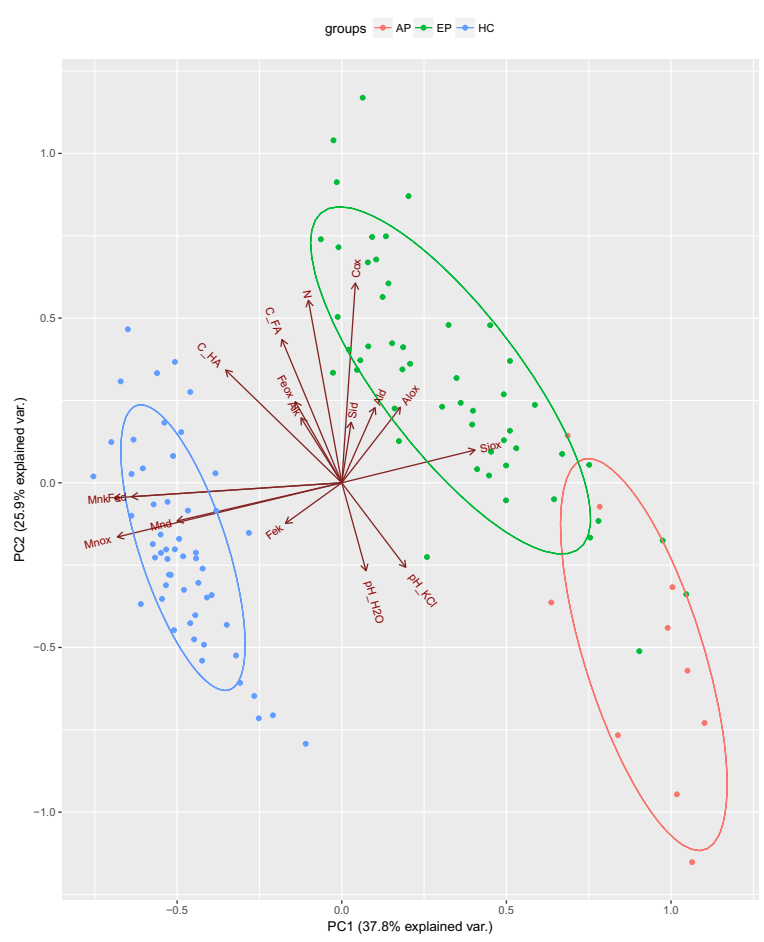

Fig. 2 Principal component analysis (PCA) biplot representing the first and the second principal components as a result of a linear combination of the response variables against the explanatory variable of the main soil regions. A PCA on a correlation matrix was used because of differences in the units of measure 
descriptive statistics (Appendix 2), and statistical test results (Appendix 3). Apart from different pedomorphologies, the main and highly significant differences in chemistry were due to the crystalline (d) and amorphous (ox) forms of $\mathrm{Fe}$ and $\mathrm{Al}$ and all forms of $\mathrm{Mn}$ $\left(\mathrm{Mn}_{\mathrm{d}}, \mathrm{Mn}_{\mathrm{ox}}, \mathrm{Mn}_{\mathrm{k}}\right)$ and Si. The most visible similarities were recorded for soil $\mathrm{pH}$ (in $\mathrm{H}_{2} \mathrm{O}$ and $\mathrm{KCl}$, there were no significant differences between regions and microsites) and carbon content in fulvic acids (C-FA). The lower amount of $\mathrm{C}$ within the entire soil profiles in Michigan (Munising) was associated with the generally low productivity of this ecosystem. Despite relatively lower amounts of $\mathrm{C}$ forms in these soils, a low buffer capacity supported their strong podzolization. The AP profiles were characterized by low values of almost all chemical variables (except for $\mathrm{pH}$ and $\mathrm{Al}_{\mathrm{k}}$ in the control profile). The podzols regions (AP, EP) formed a homogenous set of profiles in terms of $\mathrm{Mn}$ forms and $\mathrm{Fe}_{\mathrm{k}}$. The direction of the most important known gradient in the data (i.e., the exact affiliation of soil samples to the soil region) was near the longest (but generally unknown) gradient and explained $20 \%$ of the residual data variation. Soil region was significant at $p<0.001$ (Redundancy Analysis, RDA, variance partitioning; Table 2).

Soil and root system morphology in profiles - tree roots and their imprint in soils

The soils in the root zones of the studied trees showed sudden changes in their pedomorphic properties, and two sites in the Turbacz reserve were a clear example of this. The root system of a fir tree developed above and between two large blocks of sandstone (Fig. 3). Its taproot extended into a space between the sandstone to a depth of at least $160 \mathrm{~cm}$ (we did not reach the end of the root), as measured from the tree stump base (Fig. 4). We did not find any evidence (holes or displaced soil) of rock fragments altering the radial or axial growth of the taproot. Rather, we observed that the growth path adjusted to the rock fragment positions. The site had not been most likely previously occupied by a tree as we did not find relict root channels, root baumstains, or hydromorphic changes. On the upslope site of the fir stump, a record of the bioprotective function of the tree can be found (Fig. 4a).

The control profile for this site, which was $2 \mathrm{~m}$ upslope from the tree trunk, did not show any influence of large tree roots. Root channels were common in the tree-stump soil profiles, but the most distinctive features at this site were large decomposing roots that still filled the space in the soil body. Some root remnants were very wet and produced clear hydromorphic changes under or alongside the roots (gray in appearance; Fig. 5).

In Zofin, the tree roots also extended deep into the soil and markedly changed the appearance of the soil profiles. Under the tree stumps, the roots were irregular and discontinuous, with root channels and wedge-like structures reaching deep into the profiles (Fig. 6). The wedge-like structures were the places where organic matter was concentrated. Large roots predominated in the top part of the soil pedons and increased the thickness of the $\mathrm{O}$ and $\mathrm{A}$ horizons. We did not find significant differences in root architecture between flysch and granite of the same tree species, but we did find significant differences between tree species. Fir expressed marked taproots in both regions, and beech mainly had lateral roots. Some roots, taproots in particular, were in direct contact with the $\mathrm{C}$ horizon (usually within regolith but not solid bedrock). This contact potentially increased bioweathering and soil depth. The appearance of a BC horizon (substratum horizon with features of soil metamorphic processes) close to the fir taproot in the substratum of the $\mathrm{C}$ horizon represented a footprint of these processes. However, clear contact of a taproot with substratum material in deeper parts of the soil is evidence of slow metamorphic processes that most likely require decades or rather hundreds of years.

In Michigan, the Albic Podzols under tree stumps and in the control profiles exhibited the same stratigraphy of soil horizons (Fig. 7). The upper mineral A horizon was generally light (low amount of organic matter) and frequently missed. In these cases, the organic horizons (fresh or decomposed woody stump material or a sequence of litter, fermented and humification horizons) directly converted to a white, podzolic, eluvial E horizon (Fig. 7). Sharp transitions between organic material and the E horizon were more significant under decayed woody material, which may represent a pedomorphic footprint of intense podzolization and leaching due to the effect of concentrated carbon loss in the decomposition process. The white $\mathrm{E}$ horizon was followed by a dark violet illuvial spodic horizon with an accumulation of organic matter-sesquioxide complexes, Bhs, then an orange spodic Bs horizon, transitional BC, and a substratum $\mathrm{C}$ horizon. The substratum horizons were composed of bright yellow, lamellic, unconsolidated outwash material. Within the profiles and particularly within the Bhs horizon, we found a marked stone-like 



Fig. 3 The morphological properties of soil properties under tree stumps in sketches and photographs (all photos by PŠ) 


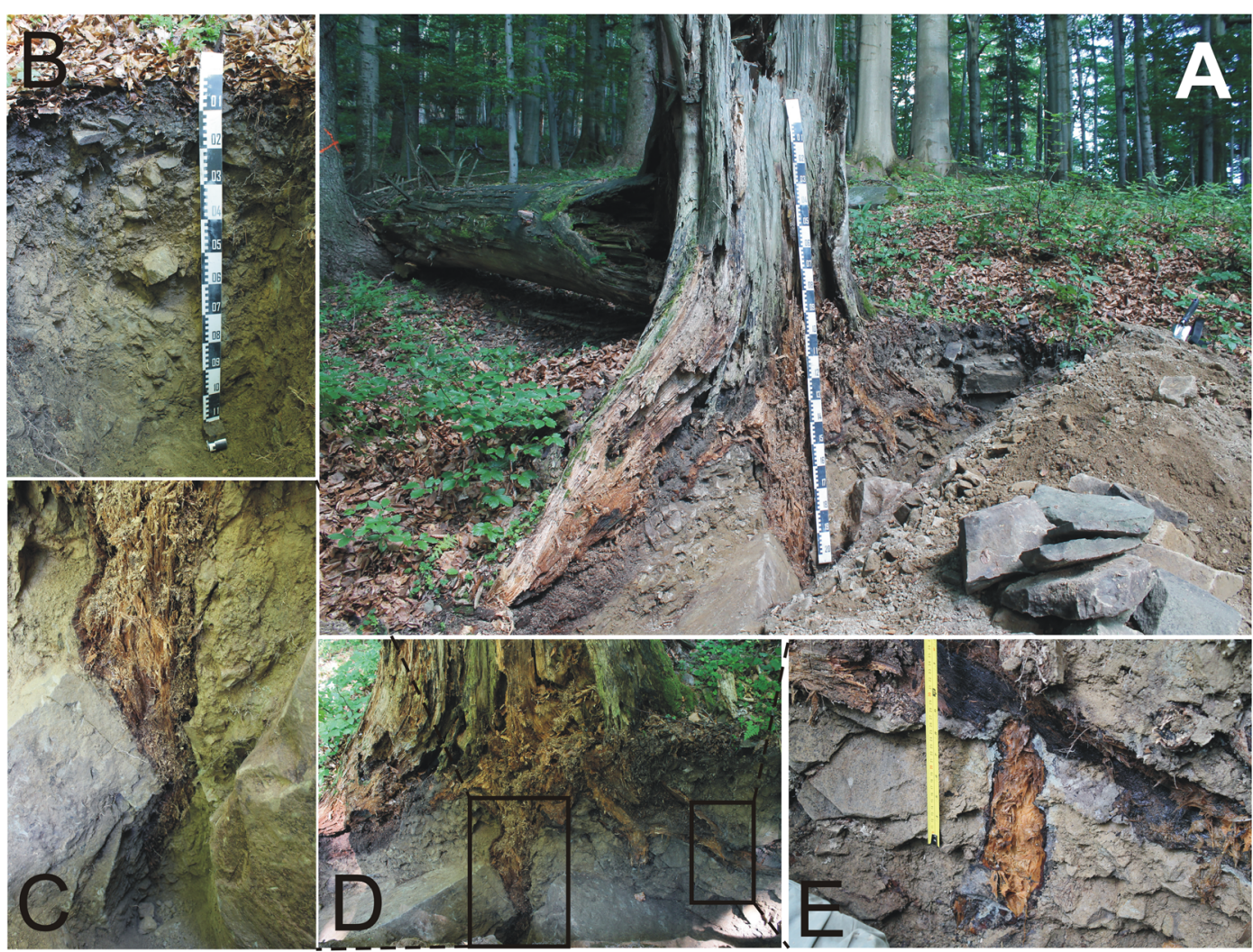

Fig. 4 Study site with a fir stump and control profile in the HC (Haplic Cambisol) region, Turbacz, Gorce, Poland (all photos by PŠ). a- general view, b - control profile, $\mathbf{c}$ - taproot growing

Bhsm horizon. This structure was developed pedogenetically and used to be called "ortsteinic" material.

Despite the same stratigraphy, the profile under the stump exhibited different thicknesses and proportions of soil horizons compared to the control profile. The most marked difference was an extremely thick E horizon under the stump (very irregular, ca. $30 \mathrm{~cm}$ deep) and a significantly shallower E horizon in the control profile $(10 \mathrm{~cm})$ (Fig. 7). The thicker eluvial part of the profile was reflected in a thicker illuvial Bhs horizon under the stump. Generally, and according to former studies, the profile under the stump is called "egg-cup podzol" or "basket podzol." The transition between the E and Bhs horizons (i.e., the transition between the eluvial and illuvial parts of the pedon) was deep under the root cylinder and main roots $(30 \mathrm{~cm}$ vs. $5 \mathrm{~cm}$ in the control profile). In total, 13 main roots were directed laterally from the root cylinder, and a taproot was not excessively developed in the Tsuga canadensis stump. We cut and excavated seven main roots, which represented an between two sandstone blocks, $\mathbf{d}$ - general view of the root system architecture, E - decomposing root and empty root channel

important factor in soil spatial variability at the pedon scale. The transitions of soil horizons were uneven everywhere but tonguing and lentil-like structures were more frequent under the stump than in the control profile and were frequently associated with the direction of roots and root channels (rare). In some cases, a thick Bhs horizon associated with the main root may have covered the Bs horizon and transitioned more sharply to the $\mathrm{BC}$ horizon.

Soil chemical changes in the root zone

\section{Differences between microsites and their main features}

The next level of variation in the data was explained by microsites, which were stumps (separate microsites were identified for each tree species) and adjacent control profiles located at a maximum distance of $10 \mathrm{~m}$ from a stump. Redundancy analysis showed that microsites explained almost $6 \%(p<0.001, \mathrm{~F}=13.99)$ of the variation in our data and proved that trees 
Fig. 5 Study site with a beech stump in the $\mathrm{HC}$ (Haplic Cambisol) region, Turbacz, Gorce, Poland (all photos by Pک̌). $\mathbf{a}$ - general view, $\mathbf{b}$ - decaying roots and empty root channels, $\mathbf{c}-$ dense network of root channels
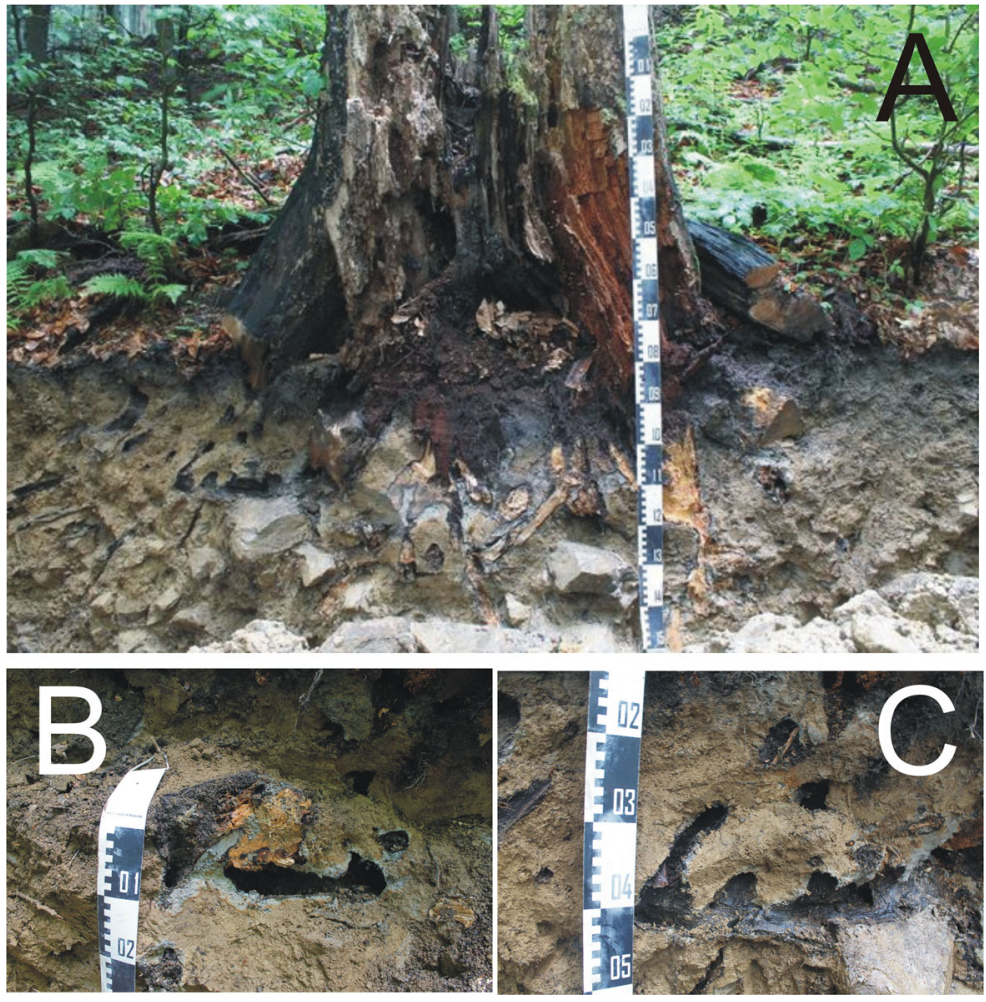

impacted soil chemical properties in the root zone (Table 3, Fig. 8). Because of data multidimensionality, this relationship was unclear and was examined on a set of separate soil profiles. Interestingly, in the AP soil region (Albic Podzol, Michigan), there were large differences in soil $\mathrm{pH}$ between $\mathrm{Hc}$ (hemlock control) and Hs (hemlock stump) sites and between soil profiles under fir and beech stumps in other regions (Fig. 8).

The depth of the analyzed soil sample under the surface was, as expected, a highly significant variable $(9.47 \%$ of explained variability of data, $p$ value $<0.001$ ) (Fig. 9).

Most of the profiles showed a normal distribution of $\mathrm{pH}_{\mathrm{H} 2 \mathrm{O}}$ and $\mathrm{pH}_{\mathrm{KCl}}$, with the lowest values in the upper horizons. These properties were predominantly associated with podzols and soil profiles under tree stumps (with a single case for each tree species). The lowest values of $\mathrm{pH}_{\mathrm{H} 2 \mathrm{O}}$ were under hemlock (AP, 3.7), beech (3.7), and fir (3.6) in Zofin (Appendix 1). In Turbacz ( $\mathrm{HC}$ region), low $\mathrm{pH}_{\mathrm{H} 2 \mathrm{O}}$ values in the upper horizons were found only under the beech stump (second profile; HC-Bs2, 4.14; abbreviations follow Appendix 1) and the fir stump (second profile; HC-Fs2, 4.15). Compared to their adjacent control profiles, the largest differences were found in EP-
Fs3 (the third soil profile under the fir stump in $\mathrm{EP}), \mathrm{AP}-\mathrm{Hs}$ and $\mathrm{HC}-\mathrm{Fs} 2$, where $\mathrm{pH}_{\mathrm{H} 2 \mathrm{O}}$ values were markedly low down to depth of $100 \mathrm{~cm}$ (in Albic Podzol stump profile). In the control profiles, only $\mathrm{EP}-\mathrm{Bc} 2$ had a lower $\mathrm{pH}$ in the top horizon.

In general, very low values of $\mathrm{N}$ and Cox were detected in all soil profiles, and they were strongly and negatively correlated with soil depth. The best values were in the control profiles EP-Bc2 and EP-Fc1, with $\mathrm{N}$ reaching $1 \%$ and $0.7 \%$, respectively, and $\mathrm{HC}-\mathrm{Fc}$, with an $\mathrm{N}$ rate of $0.5 \%$. A higher Cox content was visible in $\mathrm{EP}-\mathrm{Bc} 2(3.65 \%)$ and under the fir stump in EP-Fs1 $(1.47 \%)$. The redistribution of carbon content in humic acids (C-HA) was relatively homogenous throughout the profiles, but $\mathrm{HC}$ profiles had higher carbon content. The highest C-HA content was in EP-Bc2 (3.65\% in the $0-5$ horizon). There were much larger differences in $\mathrm{C}$ FA content, and higher values were recorded mainly under trees, with a maximum content of $2.38 \%$ in EPFs1 (fir stump 1). Very low amounts of $\mathrm{C}$ were recorded not only in AP profiles but also in $\mathrm{HC}$ profiles (Bs1 and Fs4, whole profiles). In addition, in the case of C-HA, a low $\mathrm{C}$ content was recorded in the whole EP-Fs2 profile.

The highest $\mathrm{Fe}_{\mathrm{d}}$ content was in the soil profiles under fir and in the control in $\mathrm{HC}$, with values 
Fig. 6 Study site with a fir stump in the EP (Entic Podzol) region, Zofin, Czech Republic (all photos by PŠ). a- general view, $\mathbf{b}$ modified soil horizons and remnants of tree roots, $\mathbf{c}-$ decaying roots extending into the lower horizons, $\mathbf{d}$ - decaying roots and empty root channels

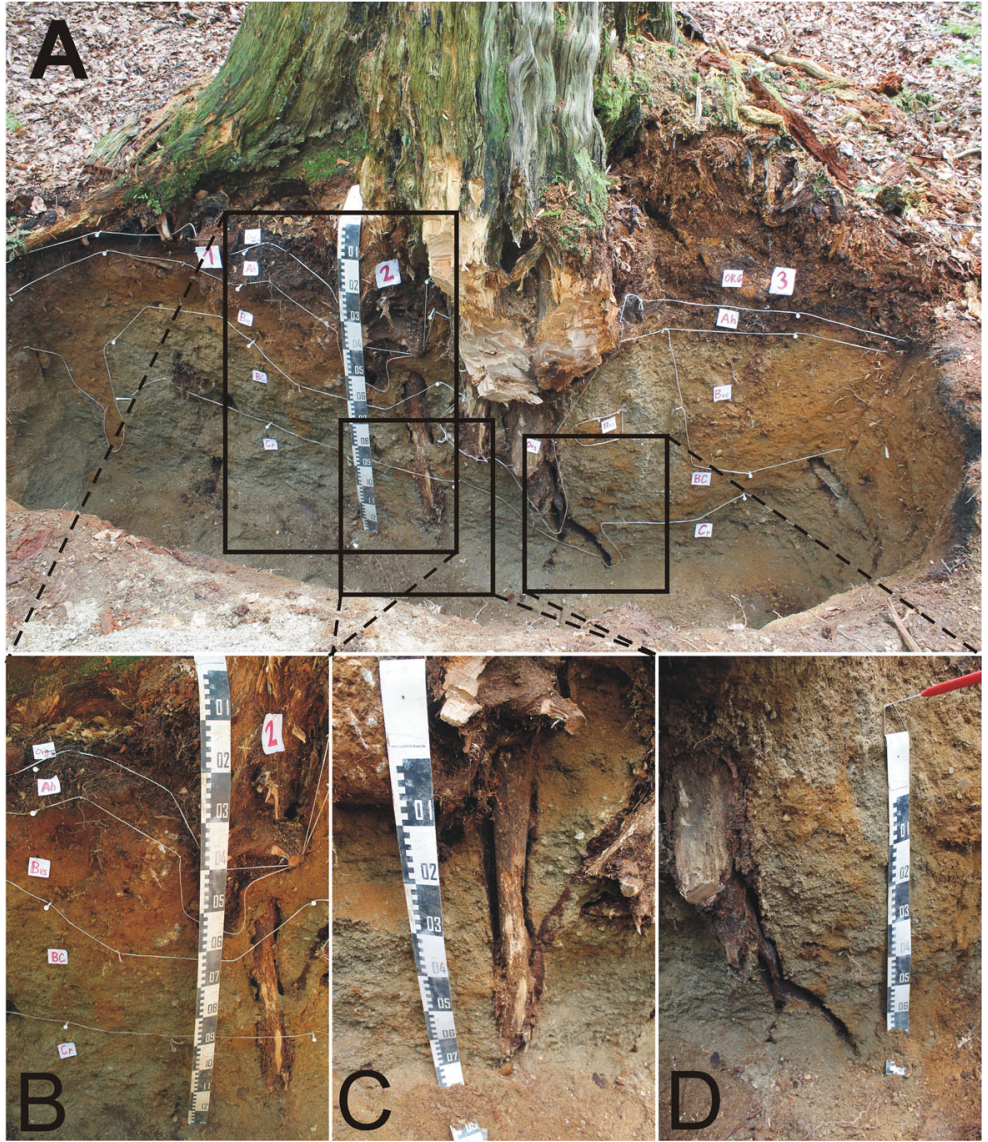

reaching $142 \cdot 10^{3} \mathrm{mg} \cdot \mathrm{kg}^{-1}$. The lowest Fe content was detected in the soil profiles in AP. Low values of $\mathrm{Al}_{\mathrm{d}}$ and low amounts of all forms of Mn were also recorded in this region. We could distinguish high contents of the following:

1) $\mathrm{Fe}_{\mathrm{ox}}$ in the $\mathrm{EP}$ control profile for beech (EP-Bc2; ca. $28 \cdot 10^{3} \mathrm{mg} \cdot \mathrm{kg}^{-1}$ ) at $9-15 \mathrm{~cm}$ depth

2) $\mathrm{Fe}_{\mathrm{k}}$ in the $\mathrm{HC}$ of the beech stump (HC-Bs3; $6.82 \cdot 10^{2} \mathrm{mg} \cdot \mathrm{kg}^{-1}$ ) in the $10-20 \mathrm{~cm}$ horizon

3) $\mathrm{Al}_{\mathrm{d}}$ in the $\mathrm{EP}$ control profile for beech $(\mathrm{EP}-\mathrm{Bc} 2$; $\left.22.3 \cdot 10^{3} \mathrm{mg} \cdot \mathrm{kg}^{-1}\right)$ in the $10-20 \mathrm{~cm}$ horizon

4) $\mathrm{Al}_{\mathrm{ox}}$ in the $\mathrm{EP}$ control profile for beech $(\mathrm{EP}-\mathrm{Bc} 2$; $\left.19.14 \cdot 10^{3} \mathrm{mg} \cdot \mathrm{kg}^{-1}\right)$ at $15-30 \mathrm{~cm}$ depth.

Increased amounts of Mn forms were observed in the control profile HC-Fc (up to $40 \mathrm{~cm}$ depth). Large regional contrasts were also detected for $\mathrm{Si}$ forms, with higher content in the control profile EP-Bc2 in the EP region $\left(3.5 \cdot 10^{3} \mathrm{mg} \cdot \mathrm{kg}^{-1}\right.$ of $\mathrm{Si}_{\text {ox }}$ within a $30-50 \mathrm{~cm}$ horizon) (Fig. 10).
Soil horizon thickness vs changes in soil chemistry

Changes in soil horizon thickness and parallel changes in soil chemistry were most clearly distinguishable in the A and B horizons of the EP soil profiles. Only the features of this soil region are described in detail.

We observed changes in the thicknesses of the $\mathrm{A}$ and $\mathrm{B}$ horizons in the EP region, from 10 (control) to $30 \mathrm{~cm}$ in the A horizon and from 30 (control) to $40 \mathrm{~cm}$ in the $\mathrm{B}$ horizon under beech. However, there were no changes in $\mathrm{A}$ and $\mathrm{B}$ horizon thickness under fir. These morphological changes were followed by changes in chemistry. Generally, we observed a decrease in all chemical properties in the A horizon under beech. For instance, C-HA and C-FA decreased in the A horizon under the beech stump as follows:

1. $0.75-1.48 \%$ of $\mathrm{C}-\mathrm{HA}$ in $0-10 \mathrm{~cm}$ of the A horizon of the control profiles, a decrease to $0.22 \%$ in 0 


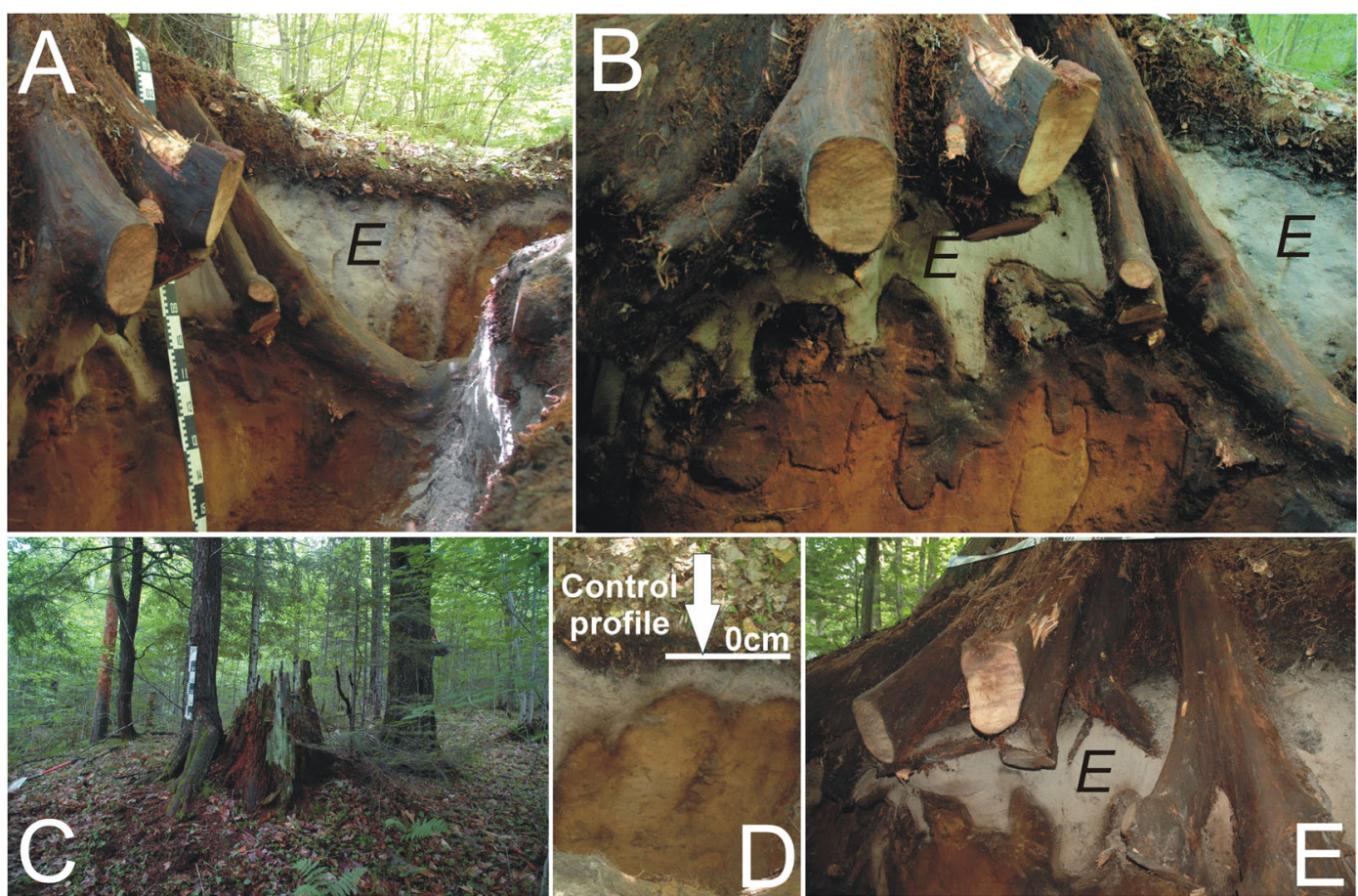

Fig. 7 Study site with a hemlock stump in the AP (Albic Podzol) region, Munising, Michigan, Upper Peninsula, USA (all photos by PŠ). a, $\mathbf{b}, \mathbf{e}$ - soil profile under tree stump from different perspectives with thick E horizon indicated, $\mathbf{c}-$ hemlock stump, $\mathbf{d}-$ control profile

$10 \mathrm{~cm}$ horizons, and a decrease to $0.39-0.75 \%$ in $10-30 \mathrm{~cm}$ horizons.

2. $1.2-1.7 \%$ of C-FA in $0-10 \mathrm{~cm}$ of the A horizon in the control profiles and a decrease to $0.6-1.18 \%$ in 0-30 $\mathrm{cm}$ horizons under the beech stump.

In terms of $\mathrm{Al}, \mathrm{Fe}, \mathrm{Mn}$ and $\mathrm{Si}$ dynamics, we describe in details only changes in $\mathrm{Al}$ content because these changes were most pronounced. Al content in the A horizons in EP under the beech stump changed depending on $\mathrm{Al}$ form, sampled profile and sampling depth. We observed a decrease in $\mathrm{Al}_{\mathrm{k}}$ from 242 to $637 \mathrm{mg} \cdot \mathrm{kg}^{-1}$ in the $0-10 \mathrm{~cm}$ horizon and a decrease to $55.4 \mathrm{mg} \cdot \mathrm{kg}^{-1}$ at the same depth in EP-Bs2. Other forms of Al increased in content but only in EP-Bs3, as follows:
1. $\mathrm{Al}_{\mathrm{ox}}$ ranged from 2400 to $3160 \mathrm{mg} \cdot \mathrm{kg}^{-1}$ in control profiles and reached $5700 \mathrm{mg} \cdot \mathrm{kg}^{-1}$ in $0-10 \mathrm{~cm}$ of the A horizon;

2. $\mathrm{Al}_{\mathrm{d}}$ ranged from 2395 to $2820 \mathrm{mg} \cdot \mathrm{kg}^{-1}$ in control profiles and reached $3960 \mathrm{mg} \cdot \mathrm{kg}^{-1}$ in the same horizon.

In the case of the $\mathrm{B}$ horizons under the beech stump in EP, we observed that the horizons not only increased in thickness from 30 to $40 \mathrm{~cm}$ but also that they migrated down the profiles, from 20 to $50 \mathrm{~cm}$ to $30-70 \mathrm{~cm}$ depth. However, changes in soil chemistry were not as obvious as they were within the A horizons. For instance, changes in $\mathrm{C}$ $\mathrm{HA}$ and C-FA were more complex, but in all

Table 3 Results of partial RDA and PCA analyses

\begin{tabular}{|c|c|c|c|c|c|}
\hline Type of ordination technique & Variable & Covariable & $\begin{array}{l}\text { Explained data } \\
\text { variability }(\%)^{*}\end{array}$ & p-level & F-value \\
\hline PCA & soil region & - & 37.80 & - & - \\
\hline $\mathrm{pRDA}$ & tree species/microsite & soil region, sample depth & 5.98 & $<0.001$ & 13.99 \\
\hline pRDA & soil region & tree species/microsite, sample depth & 20.02 & $<0.001$ & 83.86 \\
\hline $\mathrm{pRDA}$ & sample depth & tree species/microsite, soil region & 9.47 & $<0.001$ & 39.68 \\
\hline
\end{tabular}

*Presented rates of pRDA represent variation explained after removing the effects of covariables 


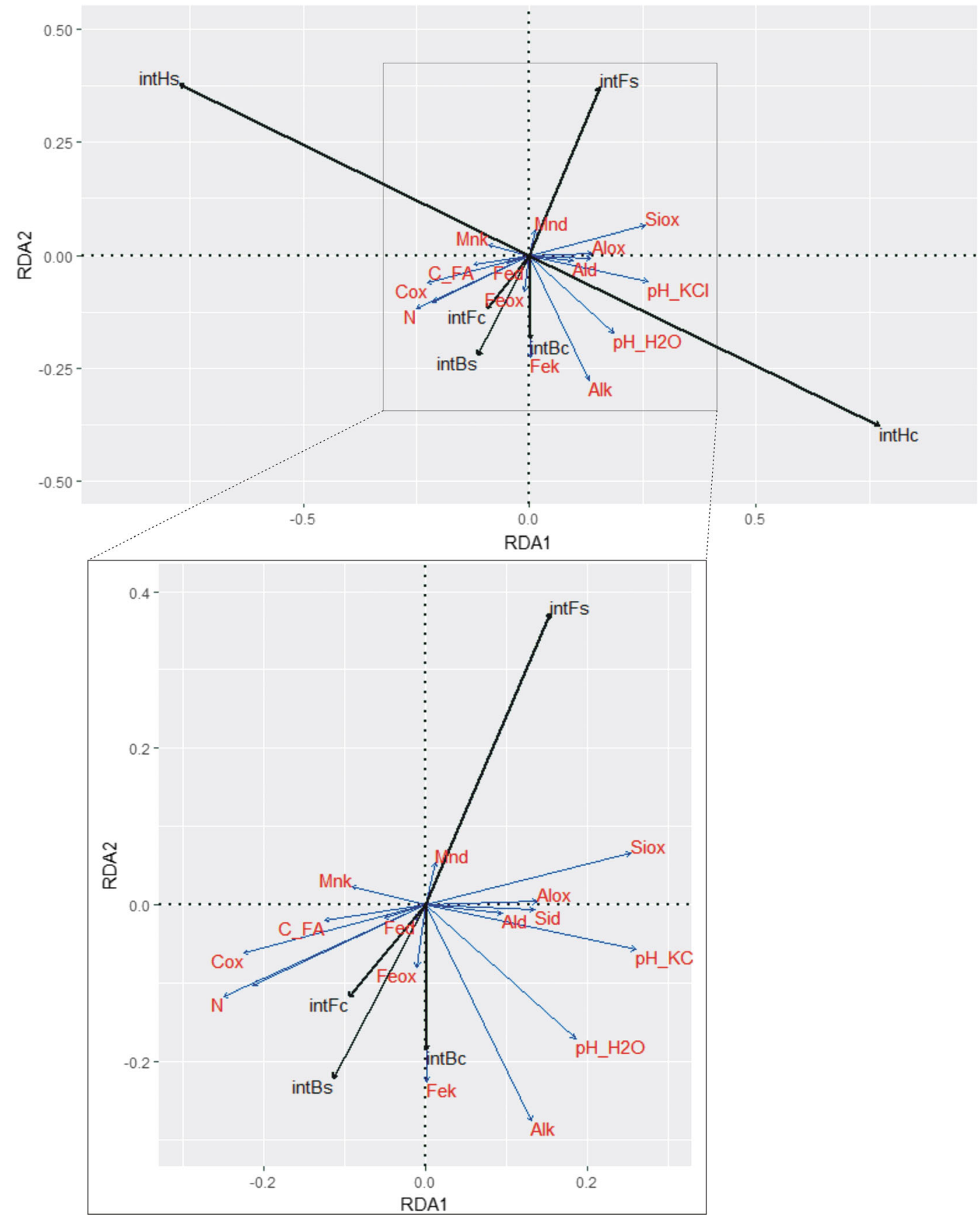

Fig. 8 Ordination diagram with results of a partial redundancy analysis (pRDA) of soil samples from three soil regions. For this analysis, the categorical variable of microsite (tree stumps and adjacent control profiles) was chosen as the main explanatory variable, and soil region and depth were covariables. The interaction between tree species and microsite explained $5.98 \%$ of the variation in the data $(p<0.001)$. For the sake of clarity, scores are not shown. The cosine of angles between thin blue vectors approximate the level of correlation between response variables they represent. If they are close to each other it indicates strong positive correlation (for instance between $\mathrm{Al}_{\mathrm{k}}$ and $\mathrm{pH}_{\mathrm{H} 2 \mathrm{O}}$ ). Interpretation for our explanatory variables (thick black vectors) is similar. Abbreviations used: "intBs" - beech stump, "intBc" - control profiles adjacent to the beech stump microsites, "intFs" - fir stump, "intFc" - control profiles adjacent to the fir stump microsites, "intHs" - hemlock stump, "intHc" - control profile adjacent to the hemlock stump microsites 


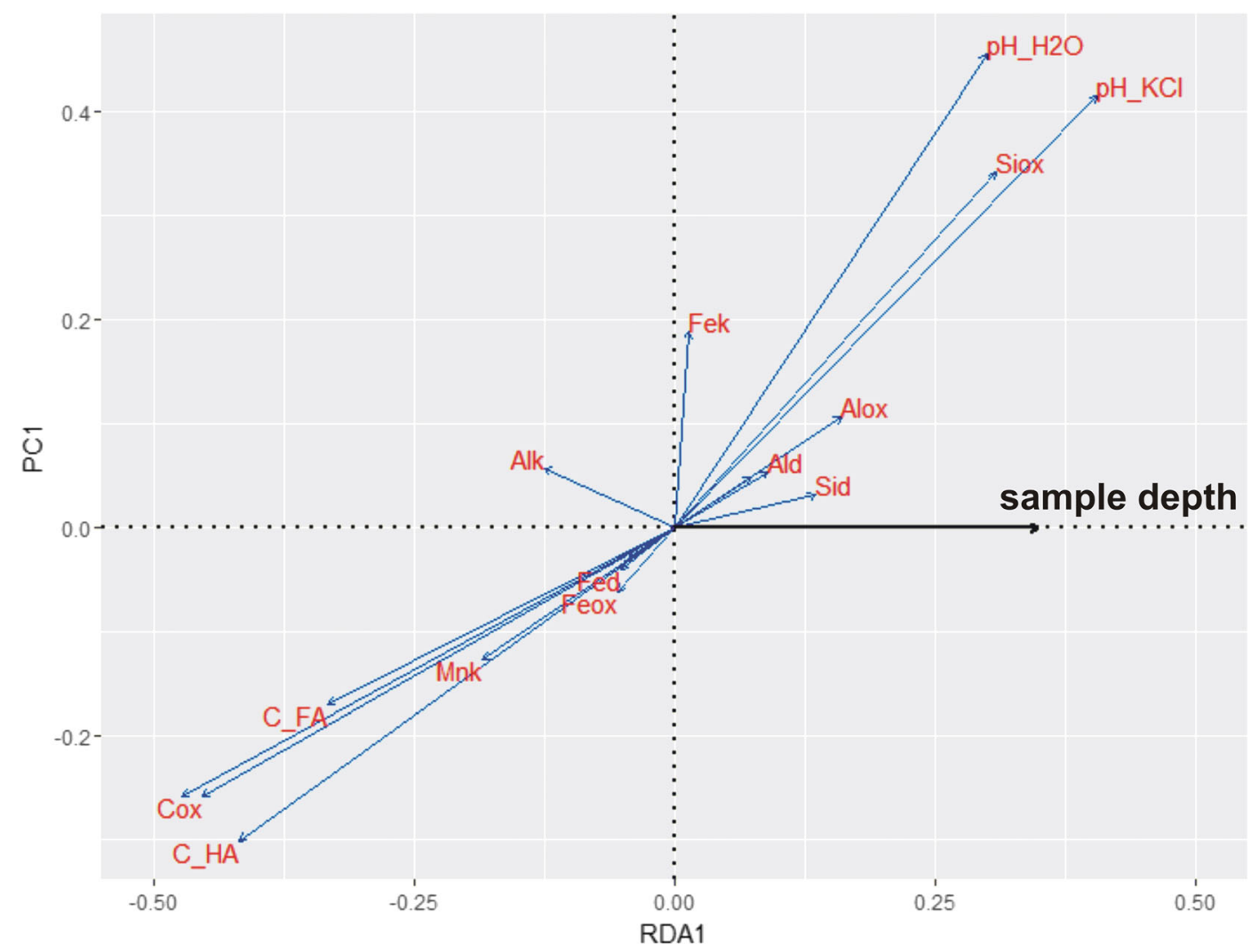

Fig. 9 Ordination diagram with results of a partial redundancy analysis (pRDA) of soil samples from three soil regions. For this analysis, the numerical variable of sample depth was chosen as the main explanatory variable. The first covariable was the interaction

cases, the lowest $\mathrm{B}$ horizons $(50-70 \mathrm{~cm}$ depth) under the beech stump contained more carbon in humic and fulvic acids than did the $30-40 \mathrm{~cm}$ $(\mathrm{EP}-\mathrm{Bc} 2)$ and $40-50 \mathrm{~cm}(\mathrm{EP}-\mathrm{Bc} 1)$ horizons in the control profiles.

$\mathrm{Al}$ content in the $\mathrm{B}$ horizons in the EP beech microsites decreased for all forms, although some irregularities appeared. $\mathrm{Al}_{\mathrm{k}}$ decreased markedly in EP-Bc2, from 500 to $775 \mathrm{mg} \cdot \mathrm{kg}^{-1}$ in the $20-30 \mathrm{~cm} \mathrm{~B}$ horizon to $145-193 \mathrm{mg} \cdot \mathrm{kg}^{-1}$ in the $50-70 \mathrm{~cm} \mathrm{~B}$ horizon. $\mathrm{Al}_{\mathrm{ox}}$ decreased from $10,000-19,140 \mathrm{mg} \cdot \mathrm{kg}^{-1}$ to $4790 \mathrm{mg} \cdot \mathrm{kg}^{-1}$ in the $30-40 \mathrm{~cm}$ B horizon in EP-Bs1. $\mathrm{Al}_{\mathrm{d}}$ decreased from 8190 to $14,000 \mathrm{mg} \cdot \mathrm{kg}^{-1}$ in the $20-50 \mathrm{~cm} \mathrm{~B}$ horizon of control profiles to $4550-7600 \mathrm{mg} \cdot \mathrm{kg}^{-1}$ at depths of $30-70 \mathrm{~cm}$ in the $\mathrm{B}$ horizons for all stump profiles.

While the thicknesses of the A and B horizons stayed almost the same under the fir tree stump, we recorded changes in soil chemistry in these horizons. $\mathrm{N}$ decreased from $0.7 \%$ in the A horizon of the control profile to $0.2-$ $0.6 \%$. Cox decreased from $7.7 \%$ to $3.8 \%$ in Fs2 but between the tree species at the locations of the stump and the adjacent control profiles, and the second covariable was soil region. Both covariables were categorical. Depth explained $9.47 \%$ of the variation in the data $(\mathrm{p}<0.001)$

increased to $13.2 \%$ in the A horizon in Fs1. Irregular behavior was also found in C-HA and C-FA contents. CHA content, which was $1.04 \%$ in the A horizon of the control profile, decreased to 0.22 in EP-Fs2, but it increased to $1.5 \%$ in other cases.

$\mathrm{Al}$ content in the A horizons $(0-10 \mathrm{~cm})$ behaved differently under fir and in the control profile. When taking into account all fir stump profiles in $\mathrm{EP}, \mathrm{Al}_{\mathrm{k}}$ decreased from $667 \mathrm{mg} \cdot \mathrm{kg}^{-1}$ to $289-415 \mathrm{mg} \cdot \mathrm{kg}^{-1}$. $\mathrm{Al}_{\mathrm{ox}}$ increased in Fs2 to $8770 \mathrm{mg} \cdot \mathrm{kg}_{-1}$ and in Fs1 to $6320 \mathrm{mg} \cdot \mathrm{kg}^{-1}$, while the initial $\mathrm{Al}_{\mathrm{ox}}$ content in the control profile was almost $5900 \mathrm{mg} \cdot \mathrm{kg}^{-1}$.

The B horizons under fir in EP also changed their chemical properties as follows:

- In Fs 2 and Fs3, $N$ content decreased $(0.08-0.25 \%$ in the control profile), reaching $0.07 \%$ at depths of 40 $50 \mathrm{~cm}$ in the B horizon in Fs3.

- Cox increased in Fs1 to $8.2 \%$ in the $10-20 \mathrm{~cm} \mathrm{~B}$ horizon. Cox decreased to $2.3 \%$ in Fs2 and $1.7 \%$ in 
Fig. $10 \mathrm{Si}_{\mathrm{d}}$ and $\mathrm{Si}_{\mathrm{ox}}$ content in all investigated soil profiles.

Abbreviations: AP - Albic Podzol, EP - Entic Podzol, HC Haplic Cambisol, $\mathrm{H}$ - hemlock, B - beech, F - fir, c - control soil profile, $\mathrm{s}-$ soil profile under tree stump

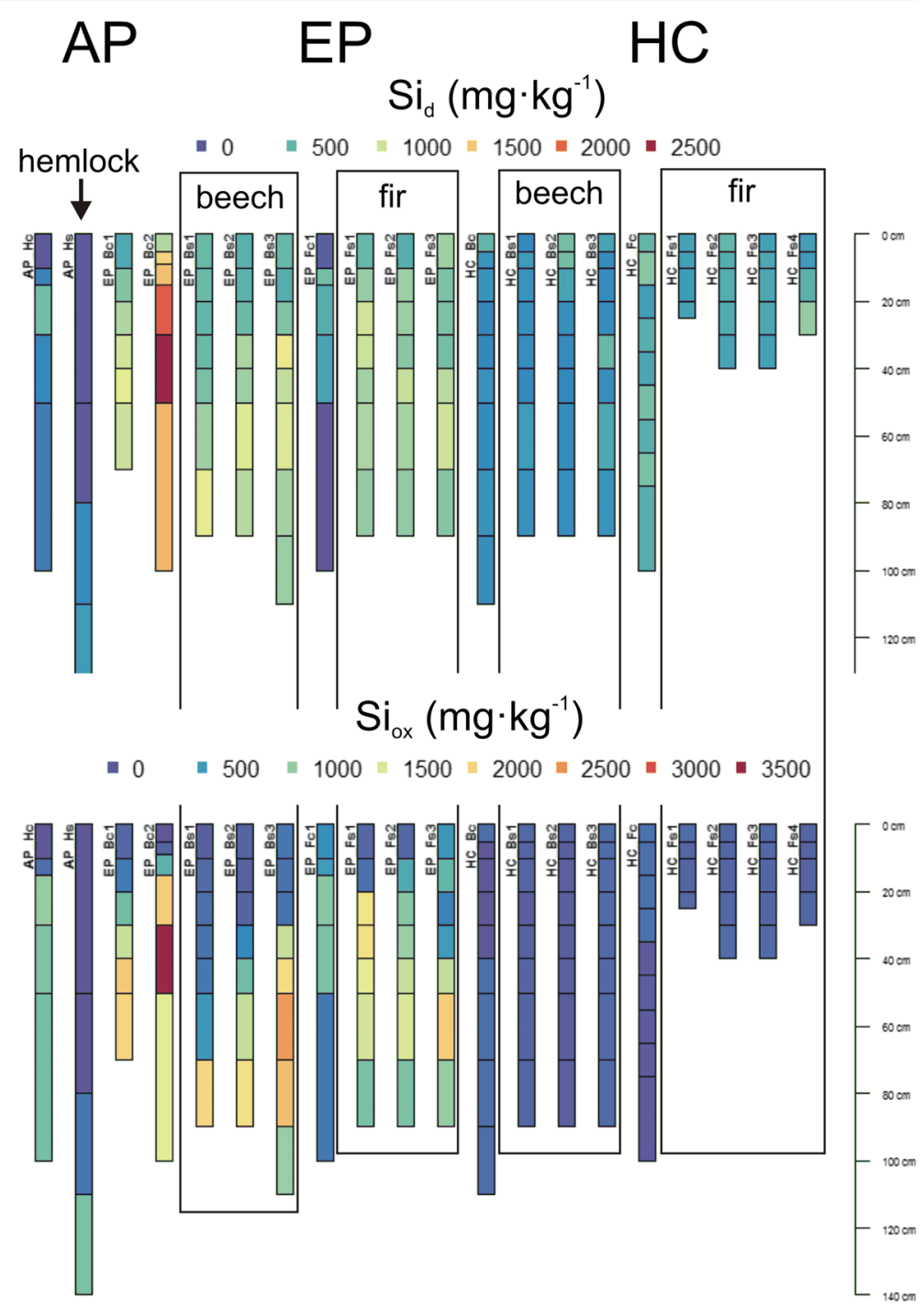

Fs3, but these values were not as low as the Cox content of $1.6 \%$ in the control profile.

- C-FA increased in Fs1 to $1.8 \%$ (control was 0.28$0.99 \%$ ), but the proportion of this chemical compound was lower in the bottom of the B horizon in Fs2 and Fs3 (0.64 and $0.35 \%$, respectively) than in the adjacent depth of the control profile.

Changes in $\mathrm{Al}$ forms under the fir stump in the $\mathrm{B}$ horizons were not as visible as they were under the beech stump.

Similar pattern of soil profile morphological changes along with changes is soil chemical properties was observed in AP (Albic Podzol) study plot (Appendix 1). The thickness of the A horizon increased from $10 \mathrm{~cm}$ (control) to $50 \mathrm{~cm}$ under the hemlock stump while a well developed $\mathrm{E}$ horizon reached $30 \mathrm{~cm}$. A decrease of soil $\mathrm{pH}$ was recorded in all horizons under the stump but the highest change was in the A horizon from 4.6 (control) to $3.7 \mathrm{pH}$. In the $\mathrm{E}$ horizon of the hemlock stump microsite (AP-Hs) all carbon content rates decreased to $0.38 \%$ (Cox) and $<0.03 \%$ (C-HA, C$\mathrm{FA})$. While the most pronounced changes in $\mathrm{Al}$ content were between 50 and $80 \mathrm{~cm} \mathrm{E}$ horizon under the stump and 15-100 $\mathrm{cm} \mathrm{B}$ horizon in the control soil profile. For instance $\mathrm{Al}_{\mathrm{k}}$ decreased from $3700 \mathrm{mg} \cdot \mathrm{kg}^{-1}$ in $30-50 \mathrm{~cm}$ (control) to $91 \mathrm{mg} \cdot \mathrm{kg}^{-1}$ in the soil profile under the hemlock stump. 


\section{Discussion}

Pedogenetic role of trees and tree roots

Through our initial assumption, we hypothesized that the morphology and physico-chemical properties of soils under trees, in the root zone and around it, differed from those of forest soils in localities not occupied by trees. Additionally, we assumed that these differences could be partly modified by regional soil properties, as it was described in case of post-uprooting pedogenesis by Šamonil et al. (2018a). Former studies, such as those by Schaetzl et al. (1989), Pawlik (2013), Shouse and Phillips (2016), suggested that trees may cause soil deepening, armoring, disintegration, displacement, mixing, inversion, up-building and removal. The authors also reported a wide range of non-linear processes in soils, with biota among the main driving factors (e.g., Phillips 1999, 2017; Gabet and Mudd 2010; Hoffman and Anderson 2014; Šamonil et al. 2014, 2015).

In the present study, we expected that in all cases, trees changed soil body hydrology through roots and root channels modifying the typical top-bottom movement of water and elements. We supposed that the root zones of forest soils were much more pedochemically active microsites that were enriched in water content and nutrients (via bioweathering processes in the rhizosphere, the activity of fine roots and mycorrhizal fungi). In some cases, these hot-spots could exist for ca. 300 years, making soils more suitable for the next generation of trees. Similar hot-spots of pedochemical activity were found in treethrow pits (Schaetzl 1990; Pawlik et al. 2017; Šamonil et al. 2018a). These hotspots were mainly associated with leaching, litter accumulation, erosion/sedimentation processes, and snow and water retention.

Trees, either living or dead, change the chemical properties of soil and regolith (e.g., Leonard and Field 2003; Gruba and Mulder 2015; Pawlik et al. 2016). Chemical differentiation of soils under the influence of trees was proved for deadwood, which affected soil through the composition of added phenolic matter (Stutz et al. 2017). Deadwood and soil under it is one of the least studied microsites. The importance of microsite type in forest floor chemistry was investigated in the flysch zone of the Western Carpathians in relation to tree-throw pits and mounds and control sites (Šamonil et al. 2008). For instance, the organic horizons in the tree-throw pits contained the lowest amounts of total humic substances and fulvic acids. While we cannot make direct comparisons to this study, the lowest carbon content in humic acids (C-HA) was under the majority of beech and fir stumps in our study, while C-FA content was lower only in AP (both profiles) and under one fir stump in HC (Fs4; Appendix 1).

When examining soils under living trees, each individual plant can be treated as a center from which soil properties change quasi-regularly (Zinke 1962). In another study, positions closest to the trunk were characterized by the lowest $\mathrm{pH}$, and this effect was associated with bark-litter chemistry and stemflow (Zinke 1962; Pallant and Riha 1990). This effect was recently exemplified by $\mathrm{pH}$ depressions detected around pine, spruce and beech trees (Gruba 2009). However, this feature was only partly demonstrated in three of our stump profiles with a lower soil $\mathrm{pH}$ in the top horizons (APHs, EP-Bs1, EP-Fs1; Appendix 1). In this context, it has to be mentioned that the soil profiles Bs1 and Fs1 (beech and fir stumps) were positioned ca. $50 \mathrm{~cm}$ left of the stump center (but still under the tree). We expect that the observed deviations towards higher soil $\mathrm{pH}$ might be due to higher slope inclination at our study sites (input of more alkaline water from higher positions) and the high $\mathrm{pH}$ of leaf litter (for instance, in $\mathrm{HC}$, the $\mathrm{pH}_{\mathrm{H} 2 \mathrm{O}}$ of the organic horizon, $\mathrm{O}_{\mathrm{L}, \mathrm{F}, \mathrm{H}}$, was 4.91 ).

Both biomechanical and biochemical effects of trees may constitute soil memory, and some important examples of soil memory include "basket" and "egg-cup" podzols (Ives et al. 1972; Phillips 1999). These podzols result from stemflow concentration and organic acids produced during the tree metabolism and trunks and roots decay. Organic acids destroy structure of primary and secondary minerals directly beneath trees (Phillips et al. 1996; Phillips 1999; Schaetzl and Thompson 2015). The effects can survive even as buried remnants of previously developed "egg-cup podzols" (Ives et al. 1972). Albic Podzols investigated in the Michigan site clearly showed features of "egg-cup podzols," including a thick E horizon under the stump and a shallower E horizon in the control profile. Root channels, which are detectable long after tree death, are definitely a good measure of soil memory, and such forms can be important indicators in paleopedological studies (Retallack 2001). In this context, we can conclude that an increase in A and B horizon thickness, which we observed under stumps, can be strengthened in the future by the next generation of trees and influence mound properties after potential uprooting. In our case, soil memory also 
includes changes in soil chemistry in the A and B horizons under tree stumps, mainly via an increase in soil $\mathrm{pH}$ and a decrease in $\mathrm{N}$, Cox, carbon content and $\mathrm{Al}$ forms.

It seems that two of the most important factors in pedogenesis are tree roots and root channels, which can be critical for the development of metamorphic B horizons (Phillips 2007). Without these hydrologic pathways (similar in form to insects and soil fauna tunnels and burrows), clay accumulation would "clog" the profile in some soil regions (Phillips 2007), limiting the depth/thickness of illuviation. These pathways are potentially important factors in pedogenesis in Haplic Cambisols, and we can assume that they are even more important in clay-rich Vertisols (WRB 2014). In Podzols, Buurman and Jongmans (2002, 2005) revealed significant proportion of root-derived organic matter in eluvial E and illuvial Bhs horizons. They suggested synchronicity in progressive deepening of $\mathrm{E}$ horizons with root decay and organic acids release in nutrient poor $\mathrm{E}$ horizon. Deeper understanding of this process, which could be important particularly in main tree root zone, requires future attention.

To sum up, the short-term effects mentioned above and documented at the research sites developed and persisted for at least 100-300 years in relation to soil age (of magnitude of $>10^{3}$ years). These effects can be seen as progressive soil development (Johnson and Watson-Stegner 1987) that is probably irreversible until tree uprooting or serious human impact on the soil.

\section{Biomechanical effects of trees}

When partly or wholly decayed, tree roots evolve into root channel forms that serve as pathways for water movement (Gaiser 1952; Dell et al. 1983). Root channels have frequently been cited as having the most important influence of tree roots on soils (Phillips 2007). However, from a biomechanical viewpoint, growing roots first make space for themselves by reorganizing soil particles in the direction of root growth (Pawlik et al. 2016). Sometimes this reorganization can result in so-called tree root mounds (i.e., soil pushed up around a tree base due to an increase in root volume) (Hoffman and Anderson 2014). Šamonil et al. (2018b) studied frequencies of 11 biomechanical effects of trees in soils in Central
European mountain old-growth forest in EP region. Root mounds were in this study associated mainly with large trees. The authors suggested formation of root mounds after significant displacement of the soil by radially growing roots. If tree roots are surrounded by rock fragments, this can result in trunk baumsteins or root baumsteins (Phillips and Marion 2006; Šamonil et al. 2018b) which are rock fragments moved by growing tree trunk or roots.

Some of the following biomechanical effects of tree roots were observed during this study:

- Empty and infilled relic root channels.

- Missing horizons or downward-shifted horizons under the trunk cylinder and large roots (no organic horizons and large fluctuations in $\mathrm{A}$ and $\mathrm{A} / \mathrm{B}$ thickness).

- Direct contact of the roots with the substratum C horizon and infilling of decayed roots by soil.

Gaiser (1952) reported that new roots were able to penetrate heavy clays by using subsoil cracks and root channels. Other important biomechanical effects of trees are soil deepening (Shouse and Phillips 2016) and infilling of stump rot pits (Phillips and Marion 2006), which were first suggested by W.M. Davis, a famous North American geographer (King and Schumm 1980). We did not observe baumsteins (rock fragments displaced by tree growth), but they were ubiquitous around other trees above our study plot in Turbacz where sandstone predominated. Soil compaction is another biomechanical influence of trees that is caused by wind loading and tree swaying (terra vibrata of F.D. Hole 1988). This effect has been only partly proved in some other studies (compaction up to $5 \mathrm{~m}$ from trees; Godefroid and Koedam 2010) because it could also be caused by human impact, such as heavy forestry machinery operating at some distance from trees (Kozlowski 1999). However, if natural, this interesting effect of living trees can be followed by other effects after tree breakage (the decay of roots, an increase in wood channel density, fluctuations in moisture content, etc.). We did not observe any noticeable changes in soil bulk density that could be attributed to it. It can also be the case that the lack of soil compaction was the result of biogenic creep (Wilkinson et al. 2009; Pawlik and Šamonil 2018). 
Properties of soil profiles under tree stumps vs. control profiles - are differences significant and explainable?

Soil region may fundamentally change the effect of trees in soils. In an extensive study established in three soil regions, Šamonil et al. (2018a) revealed pedomorphic divergence and pedochemical convergence of Albic Podzols in tree-throw microsites, whereas post-disturbance soil evolution in Entic Podzols and Haplic Cambisols showed opposite patterns. The thickness of the spodic horizon suggested that divergent pedogenesis may occur at small and localized spatial scales of pitmound complexes (Šamonil et al. 2015). Based on our present results, we can conclude that hemlock intensified pedogenesis under the stump (the podsolization rate was much faster under the stump than in the control profile), but the quality of the process was the same as in the control profile. That is, a thick eluvial horizon developed under trees in Albic Podzols, but it did not exhibit pedochemical changes in soils. In this case, we cannot speak surely about divergent soil evolution. However, this certainly increased the local variability of soils (e.g., the variability of soil horizon thicknesses). Šamonil et al. (2015) described pedochemical irreversibility of podzols in Michigan without mechanical soil disturbance and mixture. In that case observed thick $\mathrm{E}$ horizons of Albic Podzols under hemlock could be an example of divergent soil evolution as well. In contrast, in HC (flysch substratum) and EP (granite), there were some changes in the trajectory of pedochemical soil development and partial changes in soil horizonation. This result can be seen in the ordination analysis (in which stump samples explained an additional portion of the variance, especially under firs; Fig. 8) and in the soil morphology diagrams (Figs. 3, 4, 5, 6 and 7).

The most altered parts of the soil profiles under tree stumps were those in the first two to three upper horizons. These soils were under the direct influence of tree roots of different sizes. The largest roots limited the range of the $\mathrm{O}, \mathrm{A}$ and $\mathrm{A} / \mathrm{B}$ horizons. The clearest examples were when fir taproots in $\mathrm{HC}$ reached the $\mathrm{C}$ horizon down to $160 \mathrm{~cm}$. The best translocations of chemical compounds (mainly forms of $\mathrm{Fe}$ and $\mathrm{Al}$ ) were under trees in the Podzols regions (towards the "basket podzol" form in AP), which clearly showed that trees can increase soil complexity and change the trajectory of pedogenesis. However, these changes were not as considerable in terms of uprootingmicrotopography, in which case the process of tree uprooting reset the pedogenic clock and was a factor in regressive soil development (Johnson and Watson-Stegner 1987; Pawlik et al. 2013; Schaetzl and Thompson 2015). There are two importance differences between these two cases of pedogenic trajectories relating to the temporal scales of the processes. First, tree uprooting is an abrupt event (operating during seconds?), while standing trees (leaving and decaying) influence pedons within decadal and centennial timescales (and these processes continue after trunk breakage). Second, post-uprooting microtopographic forms can persist for up to several thousand years, while tree stumps can completely decompose in less than 150 years (e.g. Zielonka 2006). Qualitative differences in the mechanisms of these processes have clear imprints on the soil properties of the three contrasting microsites (tree-throw pits and mounds and pedons under tree stumps) and control pedons. In the case of soils under stumps, there was no soil mixing and up-building (as in tree-throw mounds), and there was no intensive leaching as within the tree-throw pits (Šamonil et al. 2015, 2018a). We instead observed an increase in A horizon thickness from $10 \mathrm{~cm}$ in control profiles to $30 \mathrm{~cm}$ under beech in EP and an increase in B horizon thickness from $30 \mathrm{~cm}$ in control profiles to $40 \mathrm{~cm}$ under the stump. In contrast, the thickness of the A horizon under fir in EP stayed the same $(10 \mathrm{~cm})$, and the thickness of the $\mathrm{B}$ horizon increased to $40 \mathrm{~cm}$ in only one case.

Pedogenesis under tree stumps in the context of selected theoretical approaches

The tree root zone is just a small part of the Critical Zone (Lin 2010), but this zone has probably supported life and allowed for further expansion of life through weathering and pedological processes at least since the Late Devonian, when the expansion of trees began (Pawlik et al. 2016). Moreover, soils are seen as extended composite phenotypes (Phillips 2009) and thus can be an expression of genetic information of each tree 
individual and tree species. In this context, it has been argued that trees preferably occupy the same sites, and this effect can even favor the same tree species (Phillips and Marion 2004; Phillips 2009). In other words, each species modifies the soil environment to the disadvantage of other species (Binkley and Giardina 1998). Soils have also memory and store within their body information about past changes, disturbances and states (Phillips and Marion 2004; Targulian and Goryachkin 2004). While considering soil evolution, we normally do not know its initial state. However, in European and North American temperate mountain forests, this state is typically connected with periglacial conditions in the Late Quaternary. From this time period onwards, the soils in our soil regions might have been under constant direct and indirect influence of trees. Therefore, the initial point, spatial scale (landscape and pedon), soil-forming factors (extrinsic and intrinsic) and disturbances are crucial for understanding soil complexity and can result in different evolutionary pathways (Phillips 2017).

Trees are a well-defined and measurable soilforming factor (see Phillips et al. 1996) that change soil morphology and chemical and hydrological properties. Our results showed that differences in microsites (tree stump vs. control) explain ca. $6 \%$ of the variation in the data, and we suggest that deterministic chaos could have had influenced the soil (with other explanatory factors, such as slope, precipitation and vegetation, remaining constant across individual soil regions).

From the viewpoint of biogeomorphology, trees modify hillslope surface roughness and microtopography, with potentially large impacts on hillslope morphodynamics (Pawlik 2013; Pawlik et al. 2013, 2016; Samonil et al. 2017). For example, within the forested areas of the Western Carpathians, tree uprooting and standing living and decaying trees fundamentally contribute to the activity of surficial geomorphic processes (Kotarba 1970; Dąbrowska 2009; Strzyżowski et al. 2016; Phillips et al. 2017). High-frequency and long-term uprooting events in old-growth forests could drive the entire forested landscape from earlier successional stages, influenced predominantly by abiotic geomorphic factors, to a period of biogeomorphic dominance (Phillips et al. 2017). Another critical point that has to be highlighted here is that there are two important types of tree mortality: uprooting and breakage. While the pedogenetic effects of uprooting have been deeply studied in many regions
(Beke and McKeague 1984; Veneman et al. 1984; Šamonil et al. 2018a; Schaetzl and Thompson 2015), soil development under tree stumps has been studied very rarely (Phillips and Marion 2006). However, at least $60 \%$ of trees are broken in natural forests, and all trees are cut in managed forests, which is analogous to breakage from a pedogenetic viewpoint (Šamonil et al. 2013, 2017). These two arguments suggest that there is a large research gap that, when filled, should markedly expand our knowledge of forest soils.

\section{Conclusions}

Among many non-linear factors of soil development, the impact of tree roots is one of the leaststudied issues. The results presented in this paper showed a significant influence of trees, both deciduous and coniferous, on the physical and chemical properties of forest soils. This influence is more considerable in the upper horizons of the soils being investigated. While the importance of trees as soilforming factors at the landscape scale is still debatable, there was strong evidence that trees are important at the pedon scale in terms of soil complexity and evolution. Trees affect soils through concentrated stem flow, root systems that can extend deep into the $\mathrm{C}$ horizon (taproots of firs) and the accumulation of bark and leave litter around the stump. Bioturbation caused by tree roots adds to biomechanical weathering of soil particles, and regolith and the migration of water along the main roots can facilitate biomechanical weathering of soils. The longterm effects detected in soil and attributed to tree roots include root channels, empty or infilled, which facilitate the growth of new roots and water redistribution in the root zone. This further impacts soil processes and their longevity. In the present study, the soil regions direct the main pedogenic trajectories, which are then modified at the pedon scale by individual trees and the full range of soil processes connected with them. Furthermore, there are some important differences between tree species that can be attributed to the root system architecture. Finally, we suppose trees are a factor in divergent soil evolution at the pedon scale, but further data are needed, especially data on soil chronosequences, to support this assumption. 
Acknowledgements We would like to thank the authorities of Gorce Mountains National Park and Beskydy Protected Landscape Area for their permission to study soils in the strictly protected zones. PŠ would like to thank his colleagues from the Blue Cat Research team, specifically Ivana Vašičcková and Pavel Daněk for help with data collection. We also thank to Prof. Randall J. Schaetzl and Caitlin Clark, both from Michigan State University for big support and care in Michigan. ŁP would like to express his thanks to the Rector of Pedagogical University of Cracow for his financial support of soil laboratory analyses of the samples from Gorce Mountains. The study was also supported by the Polish National Science Centre (project no. UMO-2014/15/D/ST10/04123).

PŠ would like to express his thanks for support to the Czech Science Foundation, specifically project No. 16-15319S.

\section{Appendix 1}

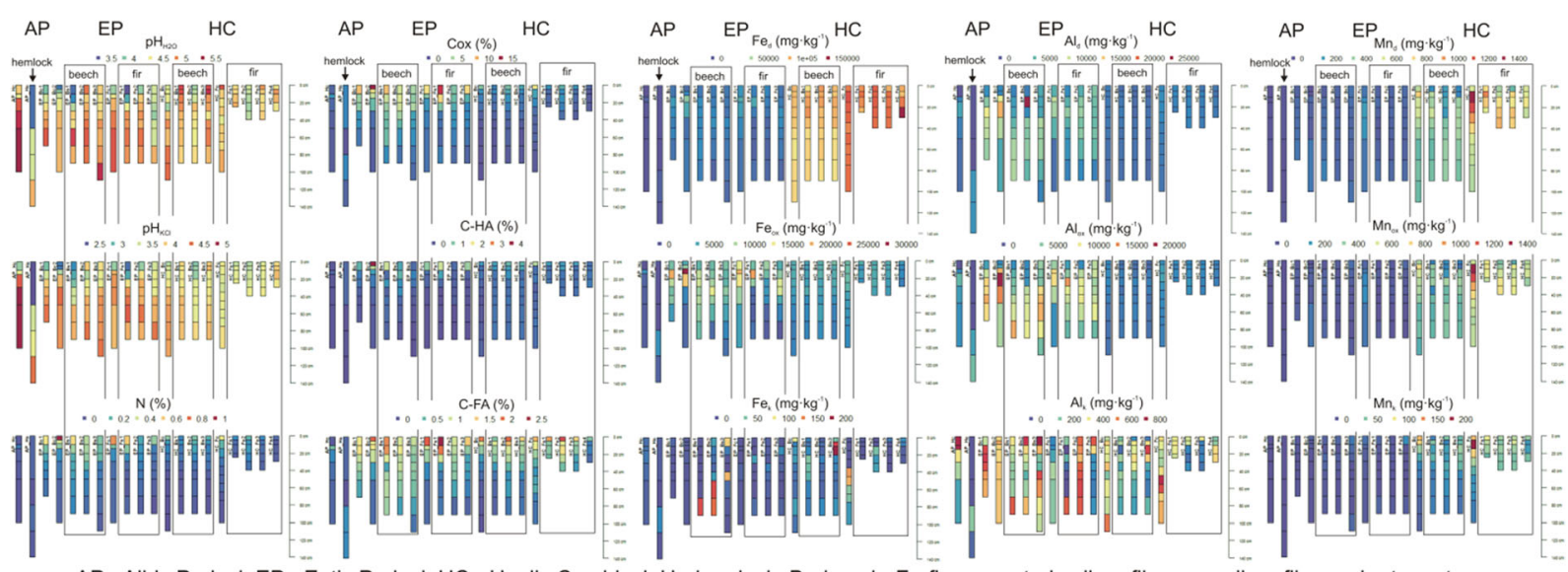

AP - Albic Podzol, EP - Entic Podzol, HC - Haplic Cambisol, H - hemlock, B - beech, F - fir, c - control soil profiles, s - soil profiles under tree stumps

\section{Appendix 2}

Table 4 Means and standard deviations of variables determined in control profiles at each soil region

\begin{tabular}{lllllll}
\hline Variable & $\mathrm{pH}_{\mathrm{H} 2 \mathrm{O}}$ & $\mathrm{pH}$ KCl & $\begin{array}{l}\mathrm{N} \\
(\%)\end{array}$ & Cox & CHA & CFA \\
\hline Soil type & \multicolumn{2}{l}{ Mean (standard deviation) } & & & & \\
AP & $4.90(0.39)$ & $4.12(0.54)$ & $0.05(0.03)$ & $1.07(0.68)$ & $0.07(0.05)$ & $0.24(0.20)$ \\
EP & 4.49 & $3.80(0.40)$ & $0.27(0.26)$ & $4.30(3.63)$ & $0.56(0.88)$ & $0.56(0.54)$ \\
HC & $(0.37)$ & $3.77(0.18)$ & $0.12(0.12)$ & $1.54(1.76)$ & $0.28(0.28)$ & $0.56(0.51)$ \\
\hline
\end{tabular}

$A P$, Albic Podzol; EP, Entic Podzol; HC, Haplic Cambisol 

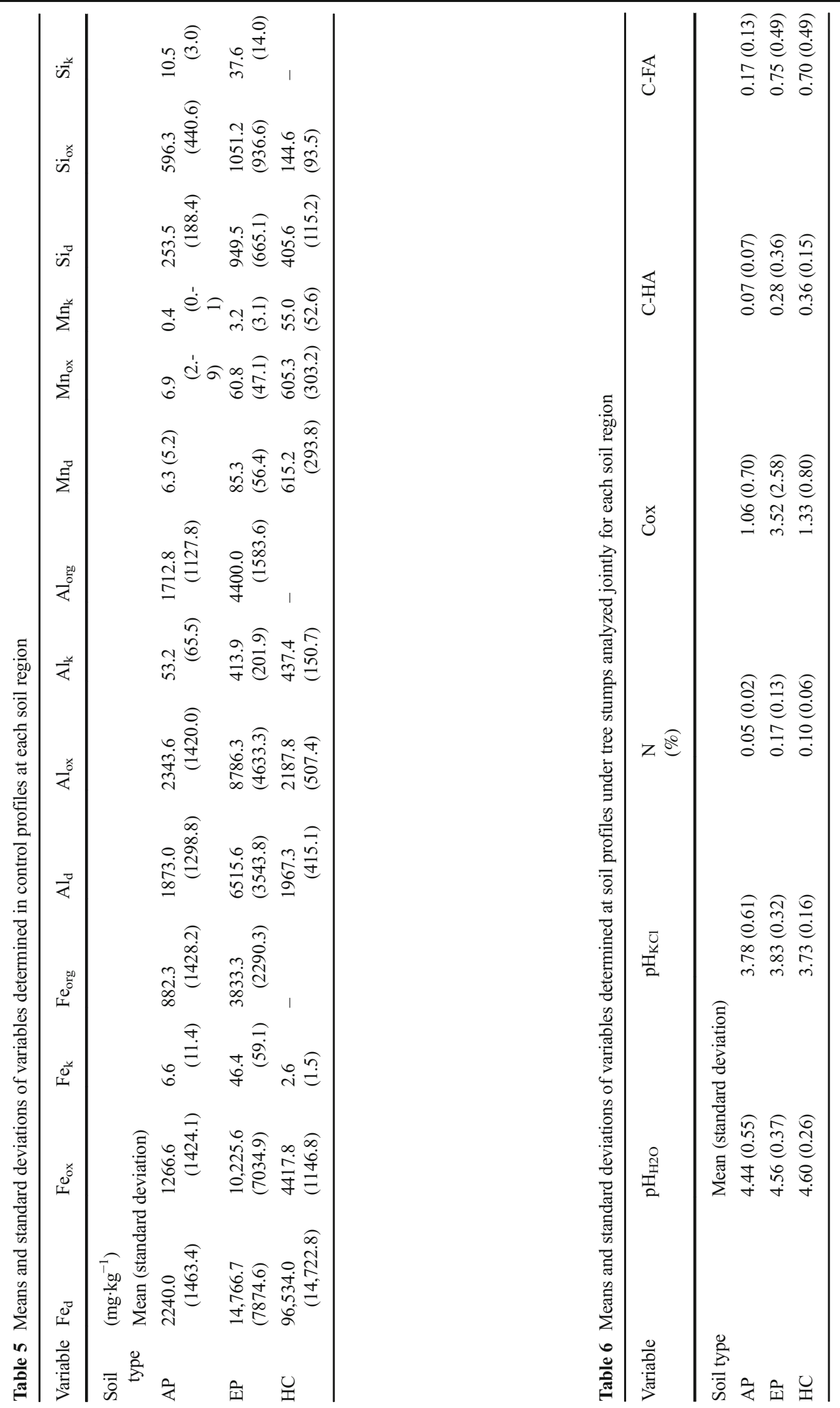


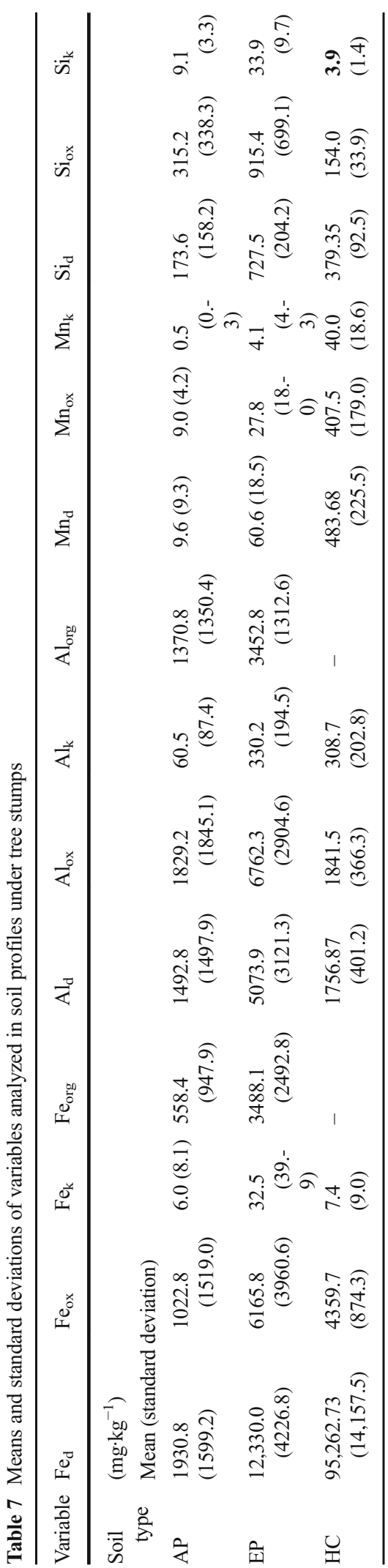

\section{Appendix 3}

Table 8 Results of the Kruskal-Wallis rank sum test and a post hoc Dunn test for multiple comparisons adjasted according to Bonferroni method

\begin{tabular}{llll}
\hline Soil element & $\begin{array}{l}\text { Microsite } \\
\text { comparison } \\
\text { during Dunne } \\
\text { test }\end{array}$ & $\begin{array}{l}\text { Adjasted } \\
\text { p-value }\end{array}$ & $\begin{array}{l}\text { Kruskal-Wallis } \\
\text { test }\end{array}$ \\
& & \\
& &
\end{tabular}

\begin{tabular}{|c|c|c|c|}
\hline \multirow[t]{2}{*}{$\underset{\text { nitrogen }}{\mathrm{N}}$} & $\begin{array}{l}\text { AP_Hs-EP_Bs } \\
\text { EP_Bs-HC_Bs }\end{array}$ & $\begin{array}{l}0.0013^{*} \\
0.0469\end{array}$ & \multirow{2}{*}{$\begin{array}{c}\text { Chi-squared }=40.7 \\
d f=9 \\
\text { p-value }<0.0001\end{array}$} \\
\hline & EP_Bs-HC_Fs & $0.009^{* *}$ & \\
\hline $\begin{array}{c}\text { Cox } \\
\text { oxidizable carbon }\end{array}$ & $\begin{array}{l}\text { AP_Hs-EP_Bs } \\
\text { EP_Bs-HC_Bs }\end{array}$ & $\begin{array}{l}0.0073^{*} \\
0.0325\end{array}$ & $\begin{array}{c}\text { Chi-squared }=52.6 \\
\mathrm{df}=9 \\
p \text {-value }<0.0001\end{array}$ \\
\hline \multirow{3}{*}{$\begin{array}{l}\text { C-HA } \\
\text { carbon content in } \\
\text { humic acidc }\end{array}$} & $\begin{array}{l}\text { AP_Hs-HC_Bs } \\
\text { EP_Fs-HC_Bs }\end{array}$ & $\begin{array}{l}0.009 * \\
0.0116\end{array}$ & \multirow{3}{*}{$\begin{array}{c}\text { Chi-squared }=39.5 \\
\text { df }=9 \\
\text { p-value }<0.0001\end{array}$} \\
\hline & AP_Hs-HC_Fs & $0.0077^{*}$ & \\
\hline & EP_Fs-HC_Fs & 0.0109 & \\
\hline \multirow{8}{*}{$\begin{array}{c}\text { C-FA } \\
\text { carbon content in } \\
\text { fulvic acids } \\
\mathrm{Fe}_{\mathrm{d}} \\
\text { crystalline form of } \\
\mathrm{Fe}\end{array}$} & $\begin{array}{l}\text { AP_Hc-EP_Bc } \\
\text { AP_Hs-EP_Bs }\end{array}$ & $\begin{array}{l}0.032 \\
0.0088^{*}\end{array}$ & $\begin{array}{c}\text { Chi-squared }=27.4 \\
d f=9 \\
\text { p-value }=0.0012\end{array}$ \\
\hline & $\begin{array}{l}\text { AP_Hc-HC_Fc } \\
\text { AP_Hc-HC_Bs }\end{array}$ & $\begin{array}{l}<0.0001 * * * \\
0.0005^{* *}\end{array}$ & \multirow{7}{*}{$\begin{array}{c}\text { Chi-squared }=101.3 \\
\text { df }=9 \\
\text { p-value }<0.0001\end{array}$} \\
\hline & AP_Hs-HC_Fs & $<0.0001 * * *$ & \\
\hline & EP_Bc-HC_Fc & $0.0009 * *$ & \\
\hline & EP_Bs-HC_Bs & $0.0046^{*}$ & \\
\hline & EP_Fs-HC_Bs & $0.0003 * *$ & \\
\hline & EP_Bs-HC_Fs & $<0.0001 * * *$ & \\
\hline & EP_Fs-HC_Fs & $<0.0001 * * *$ & \\
\hline \multirow{4}{*}{$\begin{array}{c}\mathrm{Fe}_{\mathrm{ox}} \\
\text { amorphous form of } \\
\mathrm{Fe}\end{array}$} & $\begin{array}{l}\text { AP_Hc-EP_Bc } \\
\text { AP_Hs-EP_Bs }\end{array}$ & $\begin{array}{l}0.0022^{*} \\
<0.0001 * * *\end{array}$ & \multirow{4}{*}{$\begin{array}{c}\text { Chi-squared }=57.2 \\
\mathrm{df}=9 \\
\text { p-value }<0.0001\end{array}$} \\
\hline & AP_Hc-EP_Fc & $0.0006^{* *}$ & \\
\hline & EP_Bs-HC_Bs & 0.01 & \\
\hline & EP_Bs-HC_Fs & $0.0028^{*}$ & \\
\hline $\begin{array}{l}\mathrm{Fe}_{\mathrm{k}} \\
\text { labile form of } \mathrm{Fe}\end{array}$ & $\begin{array}{l}\text { EP_Fs-HC_Bs } \\
\text { HC_Bs-HC_Fs }\end{array}$ & $\begin{array}{l}0.0116 \\
0.0499\end{array}$ & $\begin{array}{c}\text { Chi-squared }=30.6 \\
\mathrm{df}=9 \\
\text { p-value }=0.0004\end{array}$ \\
\hline \multirow{6}{*}{$\begin{array}{c}\mathrm{Al}_{\mathrm{d}} \\
\text { crystalline form of } \\
\mathrm{Al}\end{array}$} & $\begin{array}{l}\text { AP_Hs-EP_Bs } \\
\text { AP_Hs-EP_Fs }\end{array}$ & $\begin{array}{l}0.04 \\
0.04\end{array}$ & \multirow{6}{*}{$\begin{array}{c}\text { Chi-squared }=88.8 \\
\text { df }=9 \\
\text { p-value }<0.0001\end{array}$} \\
\hline & EP_Bc-HC_Bc & $0.002 *$ & \\
\hline & EP_Bs-HC_Bs & $<0.0001 * * *$ & \\
\hline & EP_Fs-HC_Bs & $<0.0001 * * *$ & \\
\hline & EP_Bs-HC_Fs & 0.0146 & \\
\hline & EP_Fs-HC_Fs & 0.0124 & \\
\hline \multirow{5}{*}{$\begin{array}{c}\mathrm{Al}_{\mathrm{ox}} \\
\text { amorphous form of } \\
\mathrm{Al}\end{array}$} & $\begin{array}{l}\text { AP_Hs-EP_Fs } \\
\text { EP_Bc-HC_Bc }\end{array}$ & $\begin{array}{l}0.0265 \\
0.0115\end{array}$ & \multirow{5}{*}{$\begin{array}{c}\text { Chi-squared }=87.0 \\
\mathrm{df}=9 \\
\text { p-value }<0.0001\end{array}$} \\
\hline & EP_Bs-HC_Bs & $<0.0001 * * *$ & \\
\hline & EP_Fs-HC_Bs & $<0.0001 * * *$ & \\
\hline & EP_Bs-HC_Fs & $0.0096^{*}$ & \\
\hline & EP_Fs-HC_Fs & $0.0007 * *$ & \\
\hline \multirow{5}{*}{$\begin{array}{c}\mathrm{Mn}_{\mathrm{d}} \\
\text { crystalline form of } \\
\mathrm{Mn}\end{array}$} & $\begin{array}{l}\text { AP_Hc-HC_Bc } \\
\text { AP_Hs-HC_Bs }\end{array}$ & $\begin{array}{l}0.0014 * \\
0.03\end{array}$ & \multirow{5}{*}{$\begin{array}{c}\text { Chi-squared }=101.4 \\
\text { df }=9 \\
\text { p-value }<0.0001\end{array}$} \\
\hline & AP_Hc-HC_Fc & $<0.0001 * * *$ & \\
\hline & AP_Hs-HC_Fs & $<0.0001 * * *$ & \\
\hline & EP_Bc-HC_Bc & 0.03 & \\
\hline & EP_Fs-HC_Bs & $<0.0015^{*}$ & \\
\hline
\end{tabular}


Table 8 (continued)

\begin{tabular}{|c|c|c|c|}
\hline Soil element & $\begin{array}{l}\text { Microsite } \\
\text { comparison } \\
\text { during Dunne } \\
\text { test }\end{array}$ & $\begin{array}{l}\text { Adjasted } \\
\text { p-value }\end{array}$ & $\begin{array}{l}\text { Kruskal-Wallis } \\
\text { test }\end{array}$ \\
\hline \multirow{8}{*}{$\begin{array}{c}\mathrm{Mn}_{\mathrm{ox}} \\
\text { amorphous form of } \\
\mathrm{Mn}\end{array}$} & EP_Bc-HC_Fc & $0.0003 * *$ & \multirow{8}{*}{$\begin{array}{c}\text { Chi-squared }=101.2 \\
\text { df }=9 \\
\text { p-value }<0.0001\end{array}$} \\
\hline & EP_Bs-HC_Fs & $<0.0001^{* * *}$ & \\
\hline & EP_Fs-HC_Fs & $<0.0001^{* * *}$ & \\
\hline & $\begin{array}{l}\text { AP_Hc-HC_Bc } \\
\text { AP_Hs-HC_Bs }\end{array}$ & $\begin{array}{l}0.001 * \\
0.0066^{*}\end{array}$ & \\
\hline & EP_Fs-HC_Bs & $0.0003^{* *}$ & \\
\hline & AP_Hc-HC_Fc & $<0.0001^{* * *}$ & \\
\hline & EP_Bc-HC_Fc & $0.0007 * *$ & \\
\hline & AP_Hs-HC_Fs & $<0.0001 * * *$ & \\
\hline \multirow{6}{*}{ 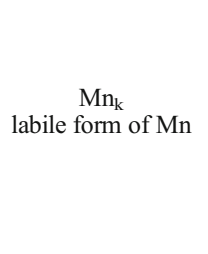 } & EP_Bs-HC_Fs & $<0.0001^{* * *}$ & \multirow{6}{*}{$\begin{array}{c}\text { Chi-squared }=95.2 \\
d f=9 \\
\text { p-value }<0.0001\end{array}$} \\
\hline & EP_Fs-HC_Fs & $<0.0001 * * *$ & \\
\hline & $\begin{array}{l}\text { AP_Hc-HC_Bc } \\
\text { EP_Bc-HC_Bc }\end{array}$ & $\begin{array}{l}0.0026^{*} \\
0.0183\end{array}$ & \\
\hline & AP_Hs-HC_Bs & $0.0009^{* *}$ & \\
\hline & EP_Bs-HC_Bs & 0.0158 & \\
\hline & EP_Fs-HC_Bs & $0.0003 * *$ & \\
\hline \multirow{12}{*}{$\begin{array}{c}\mathrm{Si}_{\mathrm{d}} \\
\text { crystalline form of } \\
\mathrm{Si}\end{array}$} & AP_Hc-HC_Fc & $0.0002 * *$ & \multirow{12}{*}{$\begin{array}{c}\text { Chi-squared }=82.2 \\
d f=9 \\
\text { p-value }<0.0001\end{array}$} \\
\hline & EP_Bc-HC_Fc & $0.001 * *$ & \\
\hline & AP_Hs-HC_Fs & $<0.0001^{* * *} *$ & \\
\hline & EP_Bs-HC_Fs & $<0.0001 * * *$ & \\
\hline & EP_Fs-HC_Fs & $<0.0001 * * *$ & \\
\hline & $\begin{array}{l}\text { AP_Hc-EP-Bc } \\
\text { AP_Hs-EP_Bs }\end{array}$ & $\begin{array}{l}0.0003^{* *} \\
0.0018^{*}\end{array}$ & \\
\hline & AP_Hs-EP-Fs & $0.0002 * *$ & \\
\hline & EP_Bc-HC_Bc & $0.0001 * *$ & \\
\hline & EP_Bs-HC_Bs & $0.0001 * *$ & \\
\hline & EP_Fs-HC_Bs & $<0.0001 * * *$ & \\
\hline & EP_Bs-HC_Fs & $0.0002 * *$ & \\
\hline & EP_Fs-HC_Fs & $0.0049 *$ & \\
\hline \multirow{2}{*}{$\begin{array}{c}\mathrm{Si}_{\mathrm{ox}} \\
\text { amorphous form of } \\
\mathrm{Si}\end{array}$} & $\begin{array}{l}\text { EP_Bs-HC_Bs } \\
\text { EP_Fs-HC_Bs }\end{array}$ & $\begin{array}{l}0.0347 \\
<0.0001 * * *\end{array}$ & \multirow{2}{*}{$\begin{array}{c}\text { Chi-squared }=49.5 \\
d f=9 \\
\text { p-value }<0.0001\end{array}$} \\
\hline & EP_Fs-HC_Fs & $0.001 *$ & \\
\hline
\end{tabular}

Abbreviations: $E P$, Entic Podzols; $H C$, Haplic Cambisols; $A P$, Albic Podzols; $F s$, fir stumps; $F c$, control profiles adjacent to fir stumps; $B s$, beech stumps; $B c$, control profiles adjacent to beech stumps; $H s$, hemlock stump; $H c$, control profile adjacent to hemlock stump

['*' adj. p-value<0.01]; [“**' adj. $p$-value $<0.001]$; [“***' adj. pvalue $<0.0001]$

Open Access This article is distributed under the terms of the Creative Commons Attribution 4.0 International License (http:// creativecommons.org/licenses/by/4.0/), which permits unrestricted use, distribution, and reproduction in any medium, provided you give appropriate credit to the original author(s) and the source, provide a link to the Creative Commons license, and indicate if changes were made.

\section{References}

Anonymous (1995) ISOIDIS 14235. Soil quality. Determination of organic carbon in soil by sulfochromic oxidation. International Organization for Standardization, Berlin, Vienna, and Zurich

Beaudette DE, Roudier P, O'Geen AT (2013) Algorithms for quantitative pedology: a toolkit for soil scientists. Comput Geosci 52:258-268

Beke GJ, McKeague JA (1984) Influence of tree windthrow on the properties and classification of selected forested soils from Nova Scotia. Can J Soil Sci 64:195-207

Binkley C, Giardina D (1998) Why do tree species affect soils? The warp and woof of tree-soil interactions. Biogeochemistry 42:89-106

Bloomfield C (1953) A study of podzolization. Part II. The mobilization of iron and aluminium by the leaves and bark of Agathis australis (Kauri). J Soil Sci 4:17-23

Brantley SL, Magonigal JP, Scatena FN et al (2011) Twelve testable hypotheses on the geobiology of weathering. Geobiology 9:140-165. https://doi.org/10.1111/j.14724669.2010.00264.x

Brantley SL, Eissenstat DM, Marshall JA, Godsey SE, BaloghBrunstad Z, Karwan DL, Papuga SA, Roering J, Dawson TE, Evaristo J, Chadwick O, McDonnell JJ, Weathers KC (2017) Reviews and syntheses: on the roles trees play in building and plumbing the critical zone. Biogeosci Discuss:1-41. https://doi.org/10.5194/bg-2017-61

Bremner JM (1996) Nitrogen-total. In: Sparks et al. (Eds.), Methods of soil analysis. Part 3. Chemical methods. Number 5 in Soil Science Society of America Book Series. Soil Science Society of America, Inc. and American Society of Agronomy, Madison. Wisconsin, pp. 1085-1121

Buttigieg PL, Ramette A (2014) A guide to statistical analyses in microbial ecology: a community-focused, living review of multivariate data analyses. FEMS Microbiol Ecol 90:543550

Buurman P, Jongmans AG (2002) Podzolization - an additional paradigm. Edafologia 9:107-114

Buurman P, Jongmans AG (2005) Podzolisation and soil organic matter dynamics. Geoderma 125:71-83

Buurman P, van Lagen B, Velthorst EJ (eds) (1996) Manual for soil and water analysis. Backhuys Publishers, Leiden, p 316

Chen Y, Senesi N, Schnitzer M (1977) Information provided on humic substances by E4/E6 Ratios1. Soil Sci Soc Am J 41(2):352

Corenblit D, Baas ACW, Bornette G, Darrozes J, Delmotte S, Francis RA, Gurnell AM, Julien F, Naiman RJ, Steiger J (2011) Feedbacks between geomorphology and biota controlling earth surface processes and landforms: a review of foundation concepts and current understandings. Earth Sci Rev 106:307-331

Courchesne F, Turmel MC (2008) Extractable Al, Fe, Mn and Si. In: Carter MR, Gregorich EG (eds) Soil sampling and methods of analysis. 2nd ed. Canadian Society of Soil Science. CRC Press, Boca Raton, pp 307-315

Dabrowska K (2009) The morphogenetic impact of the bora type wind $\left(19^{\text {th }}\right.$ November 2004) on the relief of Danielov dom area (the high Tatras). Landform Analysis 11:5-10 
Dell B, Bartl JR, Tacey WH (1983) Root occupation and root channels of jarrah forest subsoils. Aust J Bot 31:615-627

Dinno A (2016) Dunn's test of multiple comparisons using rank sums. WWW: https://cran.r-project.org

Drábek O, Borůvka L, Mládková L et al (2003) Possible method of aluminium speciation in forest soils. J Inorg Biochem 97: $8-15$

Drábek O, Mládková L, Borůvka L et al (2005) Comparison of water-soluble and exchangeable forms of al in acid forest soils. J Inorg Biochem 99:1788-1795

Dunn OJ (1964) Multiple comparison using rank sums. Technometrics 6:241-252

Favis-Mortlock D (2013) Systems and complexity in geomorphology. In: Shroder JF (ed) Treatise on geomorphology. Academic Press, San Diego, pp 257-270. https://doi. org/10.1016/B978-0-12-374739-6.00014-2

Gabet EJ, Mudd SM (2010) Bedrock erosion by root fracture and tree throw: a coupled biogeomorphic model to explore the humped soil production function and the persistence of hillslope soils. J Geophys Res 115, F04005. https://doi. org/10.1029/2009JF001526

Gabet EJ, Reichman OJ, Seabloom EW (2003) The effect of bioturbation on soil processes and sediment transport. Annu Rev Earth Planet Sci 31:249-273

Gaiser RN (1952) Root channels and roots in forest soils. Soil Sci Soc Proc 16:62-65

Godefroid S, Koedam N (2010) Tree-induced soil compaction in forest ecosystem: myth or reality? Eur J For Res 129:209217

Gruba P (2009) The influence of trees on spatial variability of $\mathrm{pH}$ in top horizons of forest soil (in polish, with English summary). Sylwan 153:332-337

Gruba P, Mulder J (2015) Tree species affect cation exchange capacity (CEC) and cation binding properties or organic matter in acid forest soils. Sci Total Environ 511:655-662

Hasenmueller EA, Gu X, Weitzman JN, Adams TS, Stinchcomb GE, Eissenstat DM, Drohan PJ, Brantley SL, Kaye JP (2017) Weathering of rock to regolith: the activity of deep roots in bedrock fractures. Geoderma 300:11-31

Hoffman HJ, Anderson RS (2014) Tree root mounds and their role in transporting soil on forested landscapes. Earth Surf Process Landf 39:711-722

Hole FD (1988) Terra vibrata: some observations on the dynamics of soil landscapes. Phys Geogr 9:175-185

Holm S (1979) A simple sequentially rejective multiple test procedure. Scand J Stat 6:65-70

Huggett RJ (1998) Soil chronosequences, soil development and soil evolution: a critical review. Catena 32:155-172

Ives D, Webb H, Jarman SM, Wardle P (1972) The nature and origin of "wind-throw podzols" under beech forest in the lower Craigieburn range, Cantenbury. New Zealand Soil News 20:161-177

Jandák T (1989) Cvičeni z půdoznalství. Vysoká škola zemědělská, Brno

Johnson DL, Watson-Stegner D (1987) Evolution model of pedogenesis. Soil Sci 143:349-366

King PB, Schumm SA (1980) The physical geography (geomorphology) of William Morris Davis. Geo Books series, Geo Abstracts Limited, Norwich, p 217

Kononova MM, Bel'chikova NP (1961) Uskorennye metody opredeleniya sostava gumusa. Pochvovedenie 10:75-87
Kotarba A (1970) The morphogenetic role of foehn wind in the Tatra Mts. Studia Geomorphologica Carpatho-Balcanica 4: 171-188

Kozlowski TT (1999) Soil compaction and growth of woody plants. Scand J For Res 14:596-619

Leonard JA, Field JB (2003) The effect of two very different trees on soil and regolitth characteristics. In: Roach IC (ed) Advances in regolith, CRC LEME, Canberra, pp 263-266

Lin H (2010) Earth's critical zone and hydropedology: concepts, characteristics, and advances. Hydrol Earth Syst Sci 14:25-45

McKeague JA, Day JH (1966) Dithionite and oxalate-extractable $\mathrm{Fe}$ and $\mathrm{Al}$ as aids in differentiating various classes of soil. Can J Soil Sci 45:13-22

McKeague JA, Brydon JE, Miles NM (1971) Differentiation of forms of extractable ion and aluminium in soils. Soil Sci Soc Am J 35:33-38

Miczyński J (2015) Klimat rządzi przyrodą. In: Czarnota P, Stefanik M (eds) Gorczański Park Narodowy. Przyroda i krajobraz pod ochroną. Wydawnictwo GPN, Poręba Wielka, pp 35-38

Mossa J, Schumacher BA (1993) Fossil tree casts in South Louisiana soils. J Sediment Petrol 63:707-713

Ogle DH (2017) FSA: fisheries stock analysis. R package version 0.8 .13

Oksanen J, Guillaume Blanchet F, Friendly M et al (2017) Package "vegan" version 2.4-3. Community Ecology Package. https://github.com/vegandevs/vegan

Pallant E, Riha SJ (1990) Surface soil acidification under red pine and Norway spruce. Soil Sci Soc Am J 54:1124-1130

Pawlik Ł, Šamonil P (2018) Soil creep: the driving factors, evidence and significance for biogeomorphic and pedogenic domains and systems - a critical literature review. Earth Sci Rev 178:257-278. https://doi.org/10.1016/j. earscirev.2018.01.008. Online first

Pawlik Ł, Migoń P, Owczarek P, Kacprzak A (2013) Surface processes and interactions with forest vegetation on a steep mudstone slope, Stołowe Mountains, SW Poland. Catena 109:203-216

Pawlik Ł, Phillips JD, Šamonil P (2016) Roots, rock, and regolith: biomechanical and biochemical weathering by trees and its impact on hillslopes - a critical literature review. Earth Sci Rev 159:142-159

Pawlik Ł, Musielok Ł, Migoń P et al (2017) Deciphering the history of forest disturbance and its effects on landforms and soils - lessons from a pit-and-mound locality at Rogowa Kopa, Sudetes, SW Poland. Bulleting of Geograpy Physical Geograpy Series 12:59-81

Phillips JD (1999) Earth surface systems. Complexity, order, and scale. Blackwell Publishers Inc., USA, p 195

Phillips JD (2001) Contingency and generalization in pedology, as exemplified by texture-contrast soils. Geoderma 102(3-4): $347-370$

Phillips JD (2006) Deterministic chaos and historical geomorphology: a review and look forward. Geomorphology 76:109121

Phillips JD (2007) Development of texture contrast soils by a combinatioin of bioturbation and translocation. Catena 70 : 92-104

Phillips JD (2008) Soil system modelling and generation of field hypotheses. Geoderma 145:419-425 
Phillips JD (2009) Soils as extended composite phenotypes. Geoderma 149:143-151

Phillips JD (2013) Nonlinear dynamics, divergent evolution, and pedodiversity. In: Ibáñez J, Bockheim J (eds) Pedodiversity. CRC Press, Boca Raton, pp 59-78

Phillips JD (2017) Soil complexity and pedogenesis. Soil Sci 182: $117-127$

Phillips JD, Marion DA (2004) Pedological memory in forest soil development. For Ecol Manag 188:363-380

Phillips JD, Marion DA (2006) The biomechanical effects of trees on soils and regoliths: beyond treethrow. Ann Assoc Am Geogr 96:233-247

Phillips JD, Perry D, Garbee AR, Carey K, Stein D, Morde MB, Sheehy JA (1996) Deterministic uncertainty and complex pedogenesis in some Pleistocene dune soils. Geoderma 73: $147-164$

Phillips J, Marion DA, Yocum C, Mehlhope SH, Olson JW (2015) Geomorphological impacts of a tornado disturbance in a subtropical forest. Catena 125:111-119

Phillips JD, Šamonil P, Pawlik Ł, Trochta J, Daněk P (2017) Domination of hillslope denudation by tree uprooting in an old-growth forest. Geomorphology 276:27-36

R Core Team (2016) R: a language and environment for statistical computing. R Foundation for Statistical Computing, Austria, Vienna URL https://www.R-project.org/

Ramette A (2007) Multivariate analyses in microbial ecology. FEMS Microbiol Ecol 62:142-160

Retallack GJ (2001) Soils of the past. An Introduction to Paleopedology, Blackwell Science Ltd, Oxford

Revelle W (2017) Procedures for Psychological, Psychometric, and Personality. R package "psych", version 1.7.5: https://cran.r-project.org/webf/packages/psych/psych.pdf

Riebe CS, Hahm WJ, Brantley SL (2017) Controls on deep critical zone architecture: a historical review and four testable hypotheses. Earth Surf Process Landf 42:128-156

Šamonil P, Šebková B, Douda J, Vrška T (2008) Role of position within the windthrow in forest floor chemistry in the flysch zone of the Carpathians. Can J For Res 38:1646-1660

Šamonil P, Schaetzl RJ, Valtera M, Goliáš V, Baldrian P, Vašíčková I, Adam D, Janík D, Hort L (2013) Crossdating of disturbances by tree uprooting: can treethrow microtopography persist for 6000 years? For Ecol Manag 307:123-135

Šamonil P, Vašíčková I, Daněk P, Janík D, Adam D (2014) Disturbances can control fine-scale pedodiversity in oldgrowth forests: is the soil evolution theory disturbed as well? Biogeosciences 11(20):5889-5905

Šamonil P, Daněk P, Schaetzl RJ, Vašičková I, Valtera M (2015) Soil mixing and genesis as affected by tree uprooting in three temperate forests. Eur J Soil Sci 66:589-603

Šamonil P, Daněk P, Adam D, Phillips JD (2017) Breakage or uprooting: how tree death type affects hillslope processes in old-growth temperate forests. Geomorphology 299:76-84

Šamonil P, Daněk P, Schaetzl RJ, Tejnecký V, Drábek O (2018a) Converse pathways of soil evolution caused by tree uprooting: a synthesis from three regions with varying soil formation processes. Catena 161:122-136

Šamonil P, Daněk P, Senecká A, Adam D, Phillips JD (2018b) The biomechanical effects of trees in a temperate forest. Earth Surf Process Landf. https://doi.org/10.1002/esp.4304. Online first
Schaetzl RJ (1990) Effects of treethrow microtopography on the characteristics and genesis of Spodosols, Michigan, USA. Catena 17:111-126

Schaetzl RJ, Thompson ML (2015) Soils - genesis and geomorphology, 2nd edn. Cambridge University Press, Cambridge, p 795

Schaetzl RJ, Johnson DL, Burns SF, Small TW (1989) Tree uprooting: review of terminology, process, and environmental implications. Can J For Res 19(1):1-11

Shouse M, Phillips JD (2016) Soil deepening by trees and the effects of parent material. Geomorphology 269:1-7

Strzyżowski D, Fidelus J, Żelazny M (2016) Geomorphological changes within a hillslope caused by a windthrow event in the Tatra Mts., Southern Poland. Geografiska Annaler: Series A, Physical Geography 98(4):347-360

Stutz KP, Dann D, Wambsganss J, Scherer-Lorenzen M, Lang F (2017) Phenolic matter from deadwood can impact forest soil properties. Geoderma 288:204-212

Targulian VO, Goryachkin SV (2004) Soil memory: types of record, carriers, hierarchy and diversity. Revista Mexicana de Ciencias Geológicas 21:1-8

Uroz S, Calvaruso C, Turpault M-P, Frey-Klett P (2009) Mineral weathering by bacteria: ecology, actors and mechanisms. Trends Microbiol 17:378-386

Veneman PLM, Jacke PV, Bodine SM (1984) Soil formation as affected by pit and mound microrelief in Massachusetts, U.S.A. Geoderma 33:89-99

Verboom WH, Pate JS (2013) Exploring the biological dimensions to pedogenesis with emphasis on the ecosystems, soils, and landscapes of southwestern Australia. Geoderma 211-212:154-183

Vincent QV (2011) ggbiplot: A ggplot2 based biplot. R package, version 0.55 . http://www.github.com/vqv/ggbiplot

Vrška T, Hort L, Odehnalová P et al (2001) The Razula virgin forest after 23 years (1972-1995). J For Sci 47:15-37

Walker LR, Wardle DA, Bargett RD, Clarkson BD (2010) The use of chronosequences in studies of ecological succession and soil development. J Ecol 98:725-736

Wei T, Simko, V (2016) Corrplot: visualization of a correlation matrix. https://www.CRAN.R-project.org/package=corrplot

Wickham H, Chang W (2016) An implementation of the grammar of graphics. http://www.ggplot2.org/

Wilkinson MT, Richards PJ, Humphreys GS (2009) Breaking ground: pedological, geological, and ecological implications of soil bioturbation. Earth Sci Rev 97:257-272

WRB (2014) World reference base for soil resources, international soil classification system for naming soils and creating legends for soil maps. In: World Soil Resources Reports No. 106. FAO, Rome

Zar JH (2010) Biostatistical analysis, 5th edn. Pearson, Harlow, p 960

Zbíral J (2002) Analýza půd I. Ústřední kontrolni a zkušební ústav zemědělský, Brno

Zbíral J (2003) Analýza půd II. Ústřední kontrolni a zkušební ústav zemědělský, Brno

Zbíral J, Honsa I, Malý S, Čižmár D (2004) Analýza půd III. Ústřední kontrolni a zkušební ústav zemědělský, Brno

Zielonka T (2006) Quantity and decay stages of coarse woody debris in old-growth subalpine spruce forests of the Western Carpathians, Poland. Can J For Res 36:2614-2622

Zinke PJ (1962) The pattern of influence of individual forest trees on soil properties. Ecology 43:130-133 